\title{
The Continuity of Vernacular Architecture amidst Changes, Village Shyopura, India
}

\author{
Ajay Kaushik $\odot$ \\ Assoc. Prof. Dr., Faculty of Planning and Architecture, Pandit Lakhmi Chand State University of Performing \& Visual Arts, \\ Rohtak, Haryana, India. Email: ajay0703@rediffmail.com
}

\section{Abstract Purpose}

The purpose of the paper is to understand the spatial structure with respect to permeability of vernacular/rural architecture of Rajasthan state in India. It also attempts to investigate the relationship of courtyard as an important aspect of rural housing.

\section{Design/Methodology/Approach}

This paper examines the typology of rural houses of a Rajasthan village built over more than a century. It justifies the continuity of typology through activities helping in understanding the vernacular environment as a concept in popular or domestic rural architecture. With the help of space syntax methods the spatial pattern and social relationship has been understood. Paper is divided in four major parts. The first part discusses the concept of vernacular along with the contextual village. The second part discusses the methodology of space syntax and method of making justified graph. The third part discusses the data analysis. Finally the conclusions are discussed. The research makes use of space syntax methodology with the help of Justified Graphs of 10 different houses of Village Shyopura in Mandawa town of district Jhunjhunu in Rajasthan state of India. These houses were built during past 125 years.

\section{Findings}

The results of the analysis show how the traditional typological approach to housing forms remains still relevant as an example of vernacular architecture. The study's aim is to avail insight into the continuity of vernacular traditions with specific interest and socio-cultural relation of spatial formation of courtyard in houses the qualitative and quantitative analysis of the study have been combined together to reach at the conclusions.

\section{Research Limitations/Implications}

Due to time limit only 10 houses have been studied in hot dry climatic region of India. There continuity of vernacular architecture can be tested by using the similar methodology use $3 \mathrm{~d}$ here to establish stronger relevance of the argument.

\section{Social/Practical Implications}

The research establishes the continuity, but on a slight note also mentions of changing architectural arrangements of vernacular houses. Conservation architects have potential work to do in such areas.

\section{Originality/Value}

The study has been conducted and tested with a unique methodology adopted in India 


\section{INTRODUCTION}

The Vernacular and traditional architecture is practiced by common man since time immemorial. This practice is a timeless way of building houses in villages in India. Most vernacular and traditional buildings are considered as 'timeless' meaning that their forms and styles are accepted as 'objects' that do not change over time. This leads to rigid definitions of domestic architecture by assigning definite cultural meanings to physical forms. While vernacular domestic spaces naturally represent the culture and society that they are constructed in, where these are interpreted in the light of fixed notions of 'culture' and 'tradition', the possibility that 'vernacular' does not necessarily mean 'timeless' or 'unchanging' is left unexplored.

International Council on Monuments and Sites (ICOMOS) published a charter on vernacular heritage describing general issues, principles of conservation, guidelines in practice of vernacular conservation. The vernacular has been defined by the in charter on the built vernacular heritage in 1999 as "A manner of building shared by the community; A recognisable local or regional character responsive to the environment; Coherence of style, form and appearance, or the use of traditionally established building types; d) Traditional expertise in design and construction which is transmitted informally; An effective response to functional, social and environmental constraints; f) The effective application of traditional construction systems and crafts" It is further described as a "traditional and natural way by which communities' house themselves" (ICOMOS, 1999, p 1).

Although, in the period of very high technological advancement, it may not be a glamorous idea the lean back on the traditional knowledge bank yet, for architects and designers of housing stock all over the world the traditional practices are important lessons in architectural practices in such areas. For many it is a nostalgic indulgences to explore more of traditional architecture and craftsmanship to meet the professional challenges (Kazimee, 2008).

Flexible and adoptable design is another hallmark of the vernacular mode of building. Housing that provides freedom of choice and is easily adoptive to changing needs and desires of the families over time are sustainable"(Kazimee, 2008, p 9). Kazimee admits that vernacular architecture has a region specific logic of construction. It infuses the intelligent use of locally available building material and craftsmanship and skilled workforce labour. As a result of which the housing is best affordable besides making such practices widely acceptable. In India there are 4 different climatic regions namely Hot and Arid Zone, Hot and Humid Zone, Warm and Humid Zone and Cold Zone (BIS 3792., 1978). Rajasthan falls under the hot and dry climate in India. The next part presents an overview of case study region in the backdrop of historical advances.

In an interview with Amos Rapoport on vernacular architecture, he defined vernacular architecture as follows Rapoport elaborates that 
high-style architecture is just a bit more elaborate. He establishes that there have always been both a "move-up" from vernacular to high-style, and a "trickle down" from high-style to vernacular and is not easy to separate them (Rapoport, 1979). Rapoport is of the opinion that primitive and vernacular buildings have co-existed, at one time or another and everywhere. However their manifestations depend upon various other factors such as: "the differences in culture, rituals, ways of life, and social organization, climates and landscapes, and materials and technology available, while the similarities are evidence not only of areas where some or all of these factors have coincided, but also of some basic constancies in man's needs and desires" (Rapoport, 1979).

\section{CONTEXT}

\section{Rajasthan}

Rajasthan was formed on 30 March 1949 as a state of India (Figure 1 \& 2). A north western state of India comprises most of the wide and inhospitable Thar Desert (also known as the "Great Indian Desert"). It borders Pakistan on west, Punjab on north, Haryana on and Uttar Pradesh on north east; and Madhya Pradesh on south east sand Gujarat on southwest. There are 33 districts, 244 tehsils, 185 statutory towns and 44, 795 villages in Rajasthan Sheopura is one of the villages in Mandawa town in district Jhunjhunu. It is district is one of the five districts, those comes under Jaipur division. There are 6 Tehsil headquarters in Jhunjhunu district (http://www.rajcensus.gov.in/.) Jain discusses the regions by citing Deryck O. Lodrick' and mentions that region can be identified in two ways. One is the perceived space or experienced region which 'represents a people's shared reaction to their particular segment of space, or specific features associated with that space, that leads to an awareness of its distinctiveness.

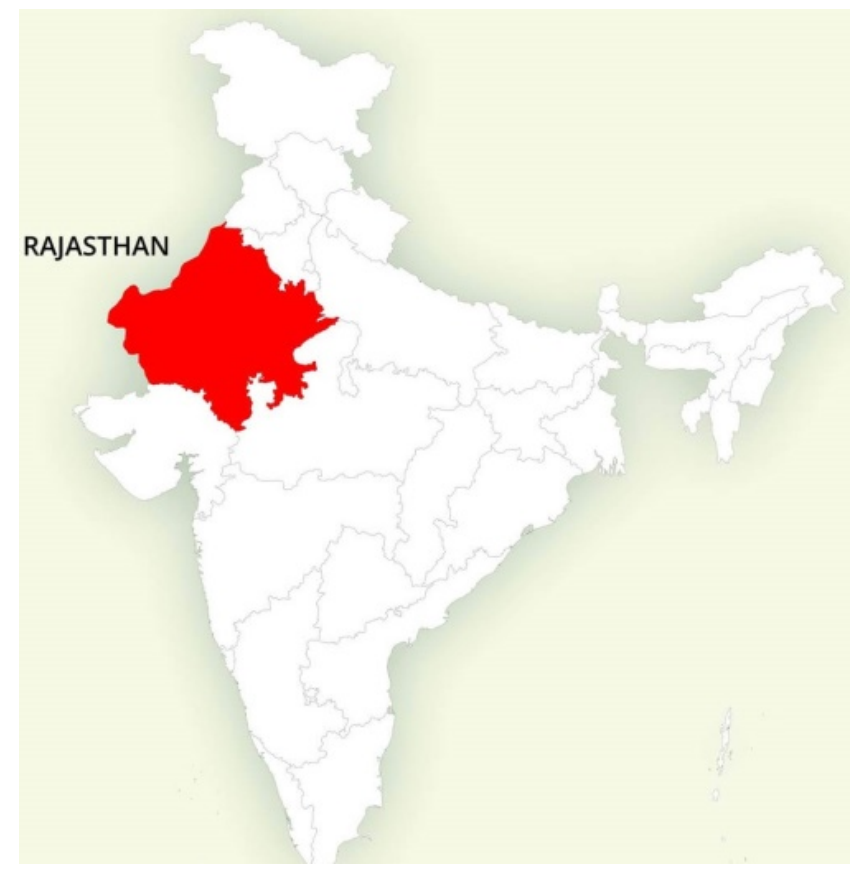




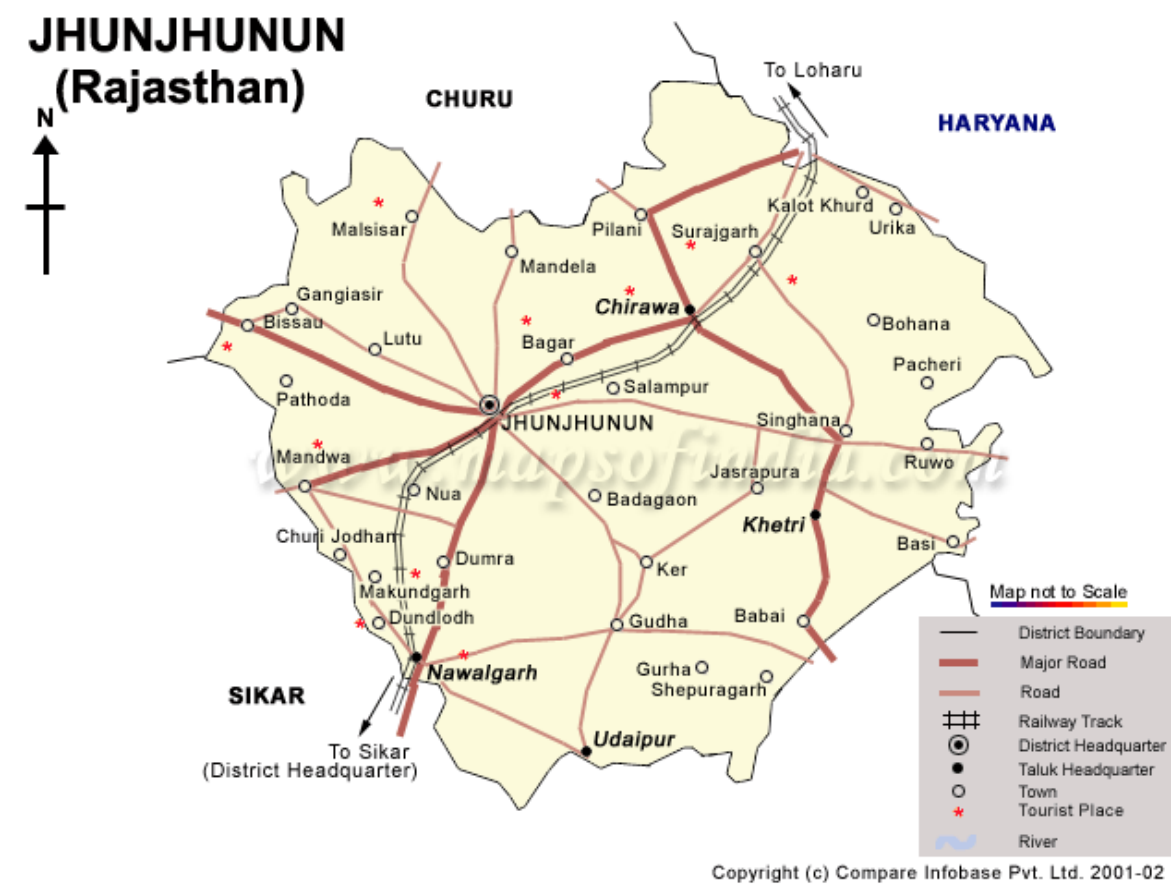

\section{Shekhawati-Mandawa}

The state is divided into Marwar Region, Shekhawati Region, Merwar Region, Dundhar Region, Mewat Brij Region, Godwad Region, Mewar Region, Hadoti Region and Vagad Region (Jain, 2002)

Mandawa fall under Shekhawati region of Rajasthan (Figure 3 \& 4). As history goes Rao Shekha, founded the Shekhawati clan. Hence the area ruled by them is known as Shekhawati. Habitation of Shekhawati can be traced back to the Harappan times with traces of Saraswati River flowing through parts of the region.

The flourishing trade activities falling enroute Bikaner and Jaipur in Shekhawati region encouraged merchants to settle in their newly established towns. The mighty Thakurs promised them economic benefits and security. Thus this was curtain raiser for a great era of building activity in Shekhawati (Shrivastva,2008).

Thus many villages got established and developed a symbiotic relationship with the town providing for the primary needs of the town and, the town in turn provided the villages with amenities of life. Nawal Singh founded Nawalgarh as his separate kingdom at the site of the village Rohelli at site of already established fort named Balaqila in 1737 AD. He expanded the village of Mandu Jat to the level of a town which later came to be known as Mandawa and founded a fort in $1756 \mathrm{AD}$ (Shrivastava, 2008). Mandawa is a town situated 190 kilometer of Jaipur in the north in Jhunjhunu district of Rajasthan in India. It comprises important a part of Shekhawati region. Mandawa is one of the twelve statutory towns of district along with Fatehpur, Dhunlod, Nawalgarh etc; (Directorate of Census Operations Rajasthan, 2011). Mandawa is known for its havelis and forts that qualify its vernacular architecture,
Figure 2. Location district Mandawa, Jhunjhunu (Image by Googlemaps \& maps of India) 
The Continuity of Vernacular Architecture amidst Changes, Village Shyopura, India

the parallel of which are available in entire geographical region of Rajasthan in one form or the other. Mandawa is a fortified town that prospered on the basis of mercantile activities (Jain, 2002). Fatehpur, Nawalgarh are nearby towns with similar growth history.
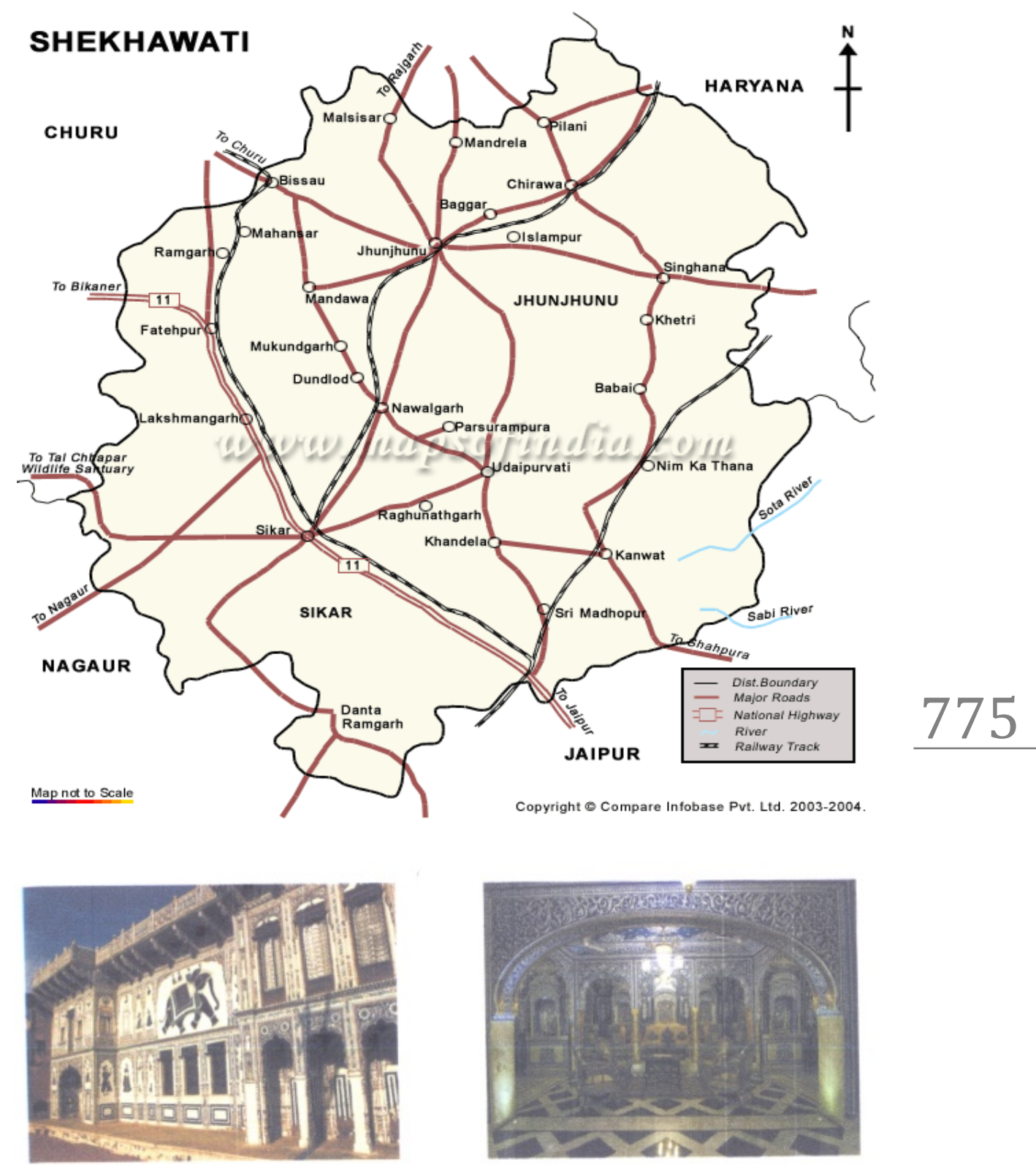

Figure 3. Shekhawati Regions (Image by www.mapsof india.com)

Figure 4. Shekhawati Regions Images (Image by Google images)
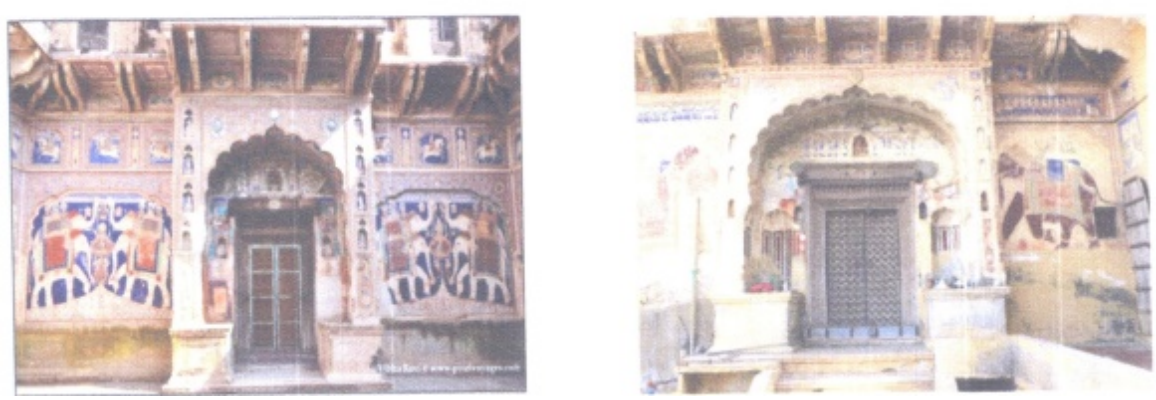
The town grew around the main bazaar street with the fort located close to it on raised ground forming the core. The town has many beautiful havelis, shops and temples the walls and ceiling of which are embellished with some of the most exquisite frescoes (Sinha \& Varshney, 2017).

The vernacular architecture of the Rajasthan provides a comfortable shelter against the harsh climatic conditions of the region (Verma et al, 2020). The vernacular architecture of Rajasthan has not been studied in the quantitative evaluation method through justified Graph method. This study is carried out on the vernacular buildings of village Shyopura in near Mandawa town of Jhunjunu District of Rajasthan India. A study of 10 vernacular residences in five categories (period of construction) namely: from 1900-1925, 1925-50, 1950-75, 1975-2000, after 2000 were studied and analysed.

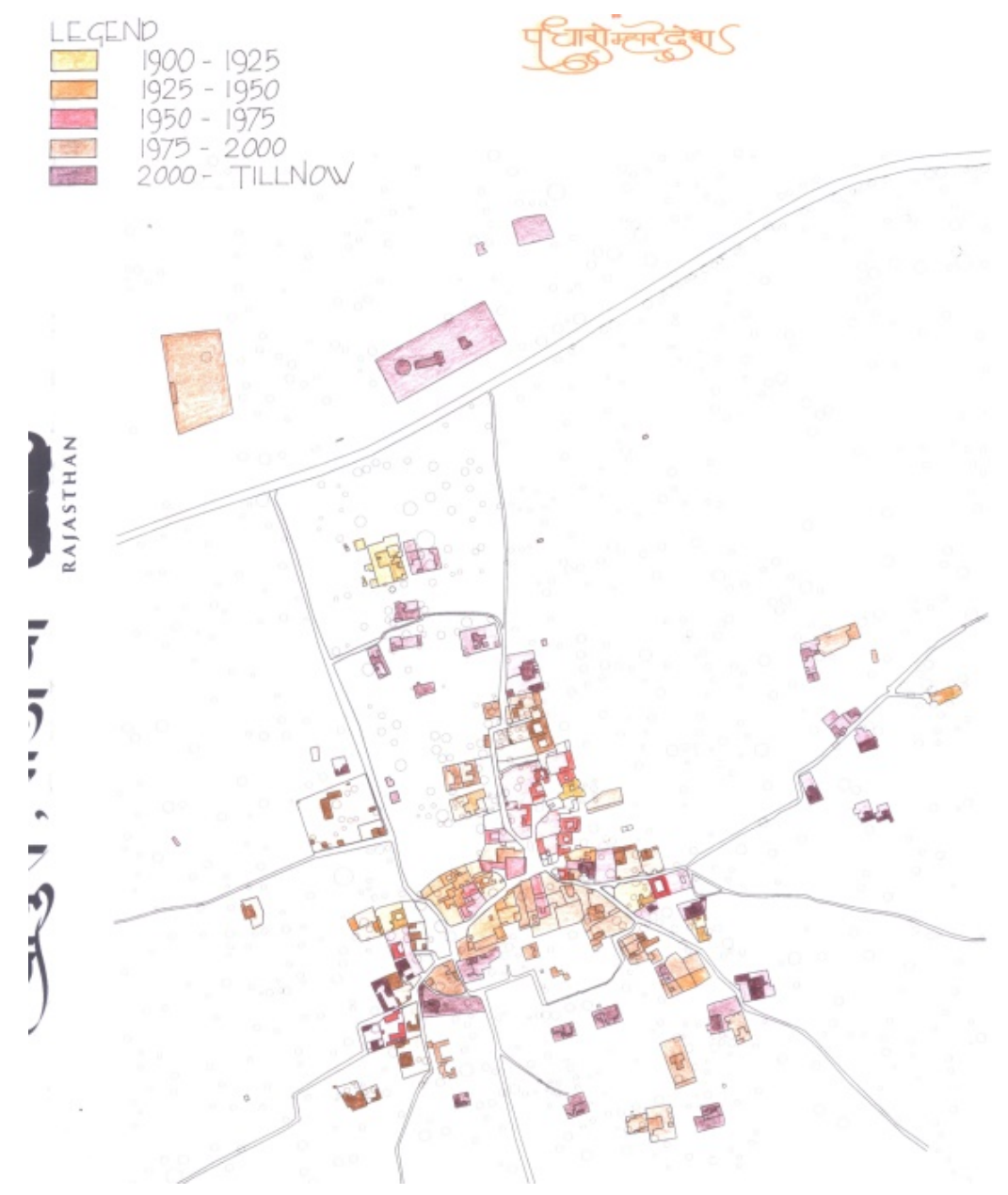

Figure 5. Time Line /period of houses in Shyopura (Drawing by Author-Studio work)

The objective of the investigation was to understand and establish the continuity of vernacular design elements with respect to significance of courtyard. The results show that their still exist the significance of court yards as one of major design elements of a house design in a village (Figure $5 \& 6$ ). 
The Continuity of Vernacular Architecture amidst Changes, Village Shyopura, India

Figure 6. Location of Courtyard houses Shyopura (Drawing by Author-Studio work)

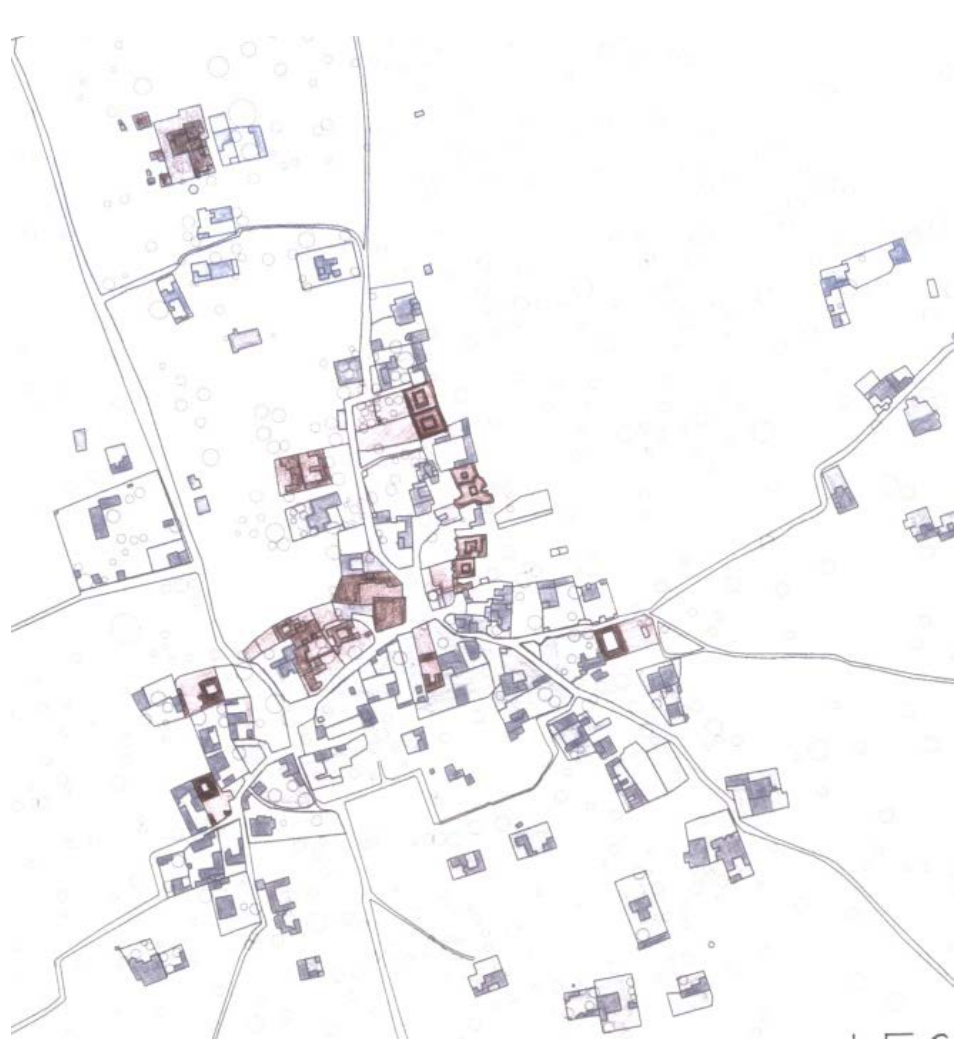

Although the traditional architecture of hot dry climatic region (Rajasthan) of India has been studied in detail in terms of climatic responsiveness (Verma et al, 2020). The familiar elements of regional architectural styles are verandahs, balconies, courtyards. The vernacular houses/ havelie's of Mandawa region are typical examples of buildings adapted to the hot and dry climate.

\section{Vernacular components}

The Basic form of house is the row house, an elongated rectangular space with central courtyard and single story have flat roofs supported on wooden members. All the space and most of daily activity are concentrated around the courtyard and organized in a system from public space to most Private spaces.

\section{Courtyard}

According to Verma et al the courtyard built form is a very suitable form for hot arid regions. This is the main reason that it forms one of the major components of vernacular design in Indian villages of hot dry region. They are usually centrally placed and are completely opened to the clear sky or partially shaded with overhangs/chhajjas in some of the cases (Verma et al, 2020). The courtyards are place that have 24 hour activity cycle. Initially the village was inhabited by 3 families. The later stage the village was divided in three parts. The belief is that puja in in the court yard. The toilets are kept preferably outside the main building. The village also has an anganwadi, graveyard, two bus stands and a water tank that is replenished by tankers. 
The stone is the easily available material. The walls are thick and heavy in older houses. The stone masonry buildings are heavy structures and store larger amount of heat due to large heat capacities and creates a larger time lag (Agrawal, Jain, \& Ahuja, 2006). This enables to keep the inside comfortable when it is very hot outside. This helps in keeping the inside cool during daytime when it is most inconvenient outside. The evidences of existence of courtyard can be traced back to $3300 \mathrm{BC}$. Courtyard houses have been a typology of houses in almost all countries of hot and dry region across all over globe. Climatically courtyard has remained one of the most significant part of lavish Havelis and vernacular houses. Traditionally the activities of family revolve around courtyard. Besides acting as an important spatial component of a house it was an important social space (Dote et al., 2018).
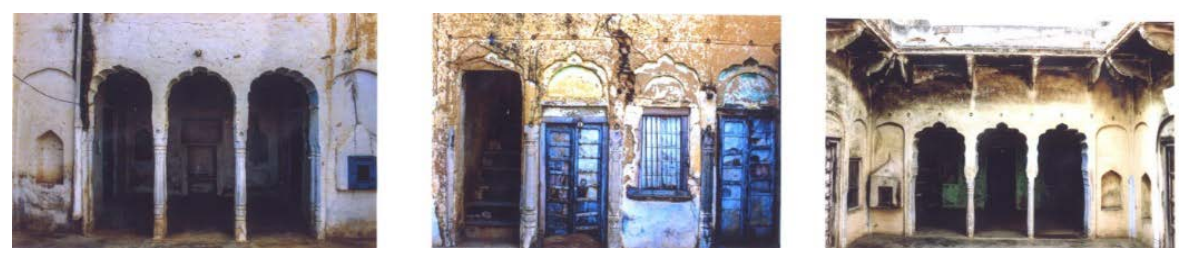

The vernacular houses which are derivation of havelis have courtyards of smaller sizes are one of the most fascinating characteristics. Various rituals and social gatherings take place in such open space / courtyard. Courtyards also act as the main connectivity to various spaces of house inside and outside. The walls around the courtyard are punctuated with arches, niches and embellished with cornices and chhajjas (Figure 7). Thus the courtyard is a transitional space between the public and the private spaces of the haveli or courtyard houses. Women and making the household chorus perform everyday activities in the courtyard and the verandahs around it. The courtyard in the night is used a sleeping in pons area under cool sky (Verma et al, 2020). The open to sky courts brings nature inside the house and create an inner microcosm of the family. In the evening time family members sits together and sleeping in summer time and throughout day most active space.

Roof

The roof is spanned with the help of stone slabs and is usually flat. The earthen pots are layered to create an insulation layer which is subsequently finished with lime mortar. Flat roofs with insulation layerthe roofs are constructed flat with stone slabs jointed with lime mortar (Figure 8).
Figure 7. Images of courtyard (Image by Author) 
The Continuity of Vernacular Architecture amidst Changes, Village Shyopura, India

Figure 8. Roof Section and Jali image (Drawing by Author-Studio work)

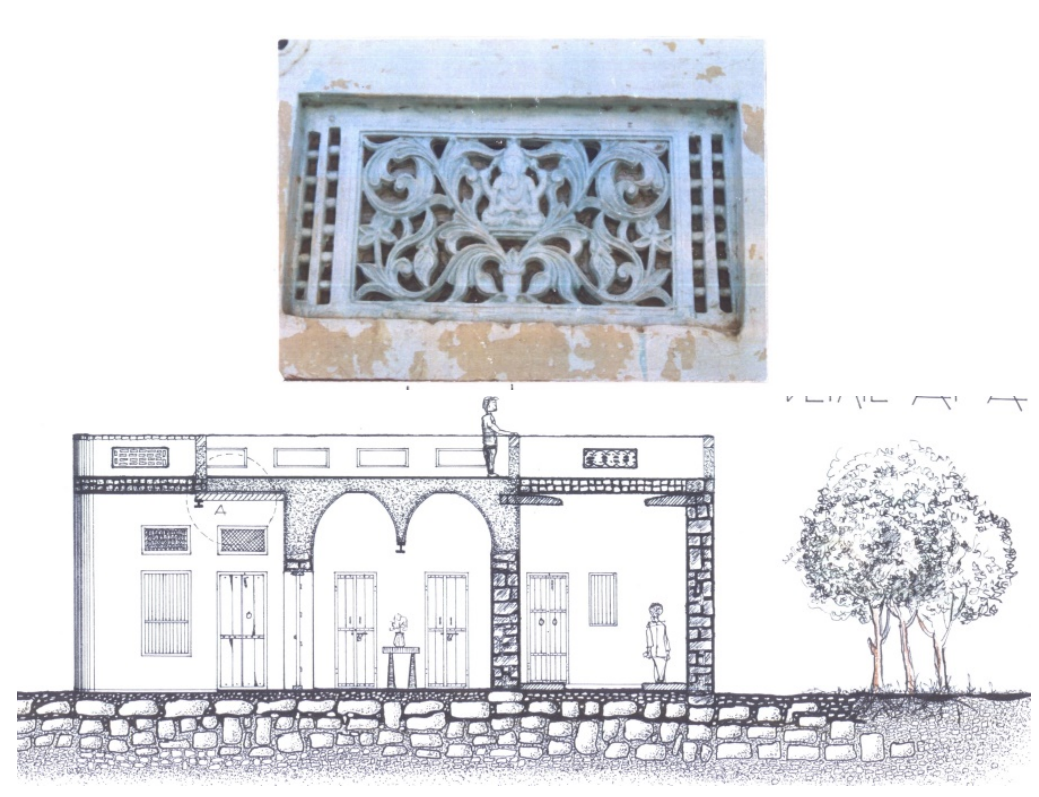

Store, kitchen and service area

One room is generally treated as store. This is usually one of the rear placed room It is usually attached with a room for and there is no ventilation. It is used for storage purpose. The households have two kitchens generally. Ladies use outdoor kitchen in morning and evening. The Research analysis uses and classify the various spaces of the houses under three broad categories as identified by Amorim (Amorim, 1997) under the

- Social sector - There are living i.e Baithak, courtyard, verandah. These spaces are the spaces where the visitors are entertained.

- Private sector - The spaces that fall in its domain are rooms, (bed rooms). These spaces are preferably are for private and personnel use by the inhabitants.

- Service sector - These sectors have store, toilets, staircase, and kitchen. The spaces for keeping cattle fall in this category (figure 9)
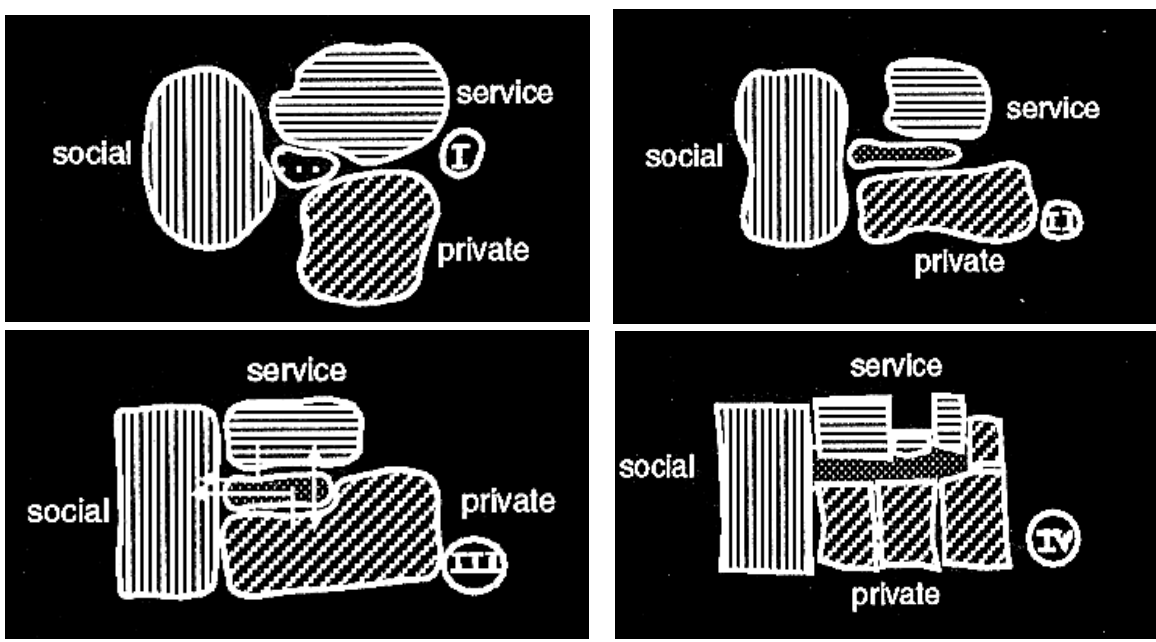

Figure 9. Classification of the key functional sectors (zones) of the house (Sketch by Amorim, 1997) 


\section{METHODOLOGY}

\section{Space Syntax}

Space Syntax is an important and significant as an analytical tool to understand urban areas. It has its application in building analysis as well. Scholars have used this method to enable better understanding of various issues pertaining of urban and rural environment. Crime study, cognitive analysis, movement pattern, legibility in urban setting, social interface, museum and shopping area study, community \& Neighbourhood, urban centers, culture and space-use, GIS and Accessibility, spatial perception of a house, configuring domestic space are some of the vital aspects related to urban and building design. Space syntax was founded by Prof. Bill Hillier and his colleagues at Bartlett School of Architecture in University College of London in the year 1984. Ever since its conception, it has gained wide spread recognition and has become an area of independent research and application.

A space is a system of interconnected units or subunits called as configuration of system. This network of interconnectivity does not take into account the metric distances, rather the topological depths are of significant importance for the description of entire system. This probably provides an objective and quantitative correlational measure of one unit with the rest of the system (Jiang, Claramunt, \& Klarqvist, 2000). Space syntax analysis was used with the aim of understanding how social relations express themselves through spatial configuration, focusing on the morphology of spaces. Space syntax thus provides a different way of looking at spatial configurations which allows comparative results between different building structures (Monteiro, 1997).

\section{Justified Graph}

To develop a justified graph (Figure 10) first one has to draw axial map. The justified graph is made by using circle representing axial lines and each linking lines between circles represent nodes or intersections. Thus one can easily show each space on the map. The shape and size of justified graph completely depends on the density of network of streets/spaces and how interconnected the streets/spaces are. The shallow graph means that passing from one space to the other is easier. Whereas, the deeper graph represents the difficulty in accessibility.
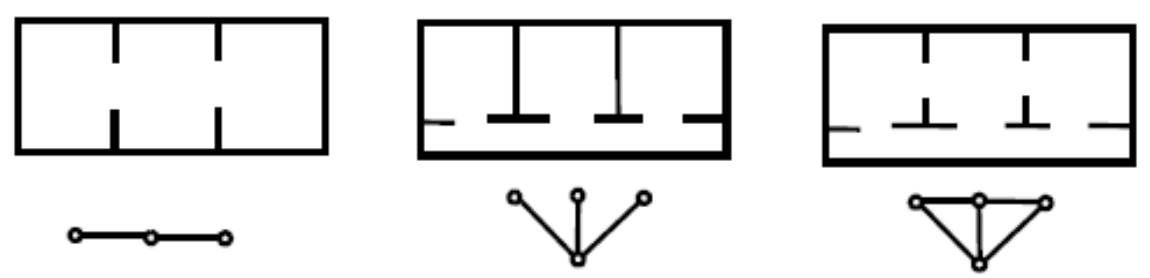

Figure 10. Justified Graph (Sketch by Jiang 2000)

"Firstly, Justified Graphs were created in which each space of the house is represented with a node and the access routes between each node as 
links. This analysis was then used to measure the depth between each space to all other spaces within a building. The entrance of each house is taken as a reference point in order to define the 'deepness' or 'shallowness' of each space in relation to the rest of the configuration. Also, Space Type Analysis was used to define the number of connections of each space within the configuration". (Gozde, 2017, p 5) Finally, each analysis is mainly discussed through two main quantifiable measurements that are the Integration and Control values. The Integration value represents the degree to which a space is integrated globally within a configurational system.

The Justified Plan Graph or JPG technique was developed in the late 1970s and was further refined in next two decades. It was established as analytical means of undertaking qualitative and quantitative research into the spatial structure or permeability of buildings (Ostwald, 2011). The paper uses the Justified Plan Graph (JPG) method to construct a graphical, mathematical and theoretical analysis of the spatial configuration of the twenty-two rural / vernacular houses of village Sheopura in town Mandawa of Rajasthan. They are typological representative of courtyard houses with changing morphology over 125 years.

While the theory and use of the JPG is well developed (Bill Hillier; Julienne Hanson, 1986), However, it has not been applied for the analysis of vernacular houses of Rajasthan. For the purpose of analysis software AGRAPH is used. While studying and analysis large number of apartments, AGRAPH WAS is developed BY Benedict Manum for his PhD-study at the Oslo School of Architecture and Design (Manum, Rusten, \& Benze, 2005).

The connectivity graph image is drawn, then AGRAPH generates a "connectivity matrix" (listing whether nodes are connected or not) and an "internal distance matrix" by simple calculations on these matrixes, the Space Syntax parameters of the nodes are determined with the help of following.

AGRAPH calculates the parameters Control Value (CV), Total Depth (TD), Mean Depth (MD), Relative Asymmetry (RA) and the integration value.

\section{Data Analysis}

The JPG of the houses was made by inserting jpeg image of houses in the AGRPAH software and then running the analysis. Following is the terminology used for the construction of JPG of ten houses.

CY - Courtyard, Int CY - Internal Courtyard, Rear CY - Rear Courtyard, V - Verandah, Root- External Root space, BA - Baithak, CT Cattle space, ST - Staircase, S - Store, K - Kitchen, R - Room, Cor - Corridor, T - Toilet. “ i values may be used in architectural analysis to understand the spatial structure relationship through development of an "inequality genotype", practice, an inequality genotype is a list of spaces in the JPG, arranged in order from highest to lowest i value. But in order to 
interpret what this list means, we have to leave behind the mathematics and start to consider wider social and cultural factors that are part of graph theory" (Ostwald, 2011).

\section{Case study - Houses}

Houses during period 1900-1925 - An analysis (Figure 11)

Out of various examples one from each of five period categories is discussed. The spatial analysis is discussed as follows. The houses were located to have been constructed during the period 1900-1925.
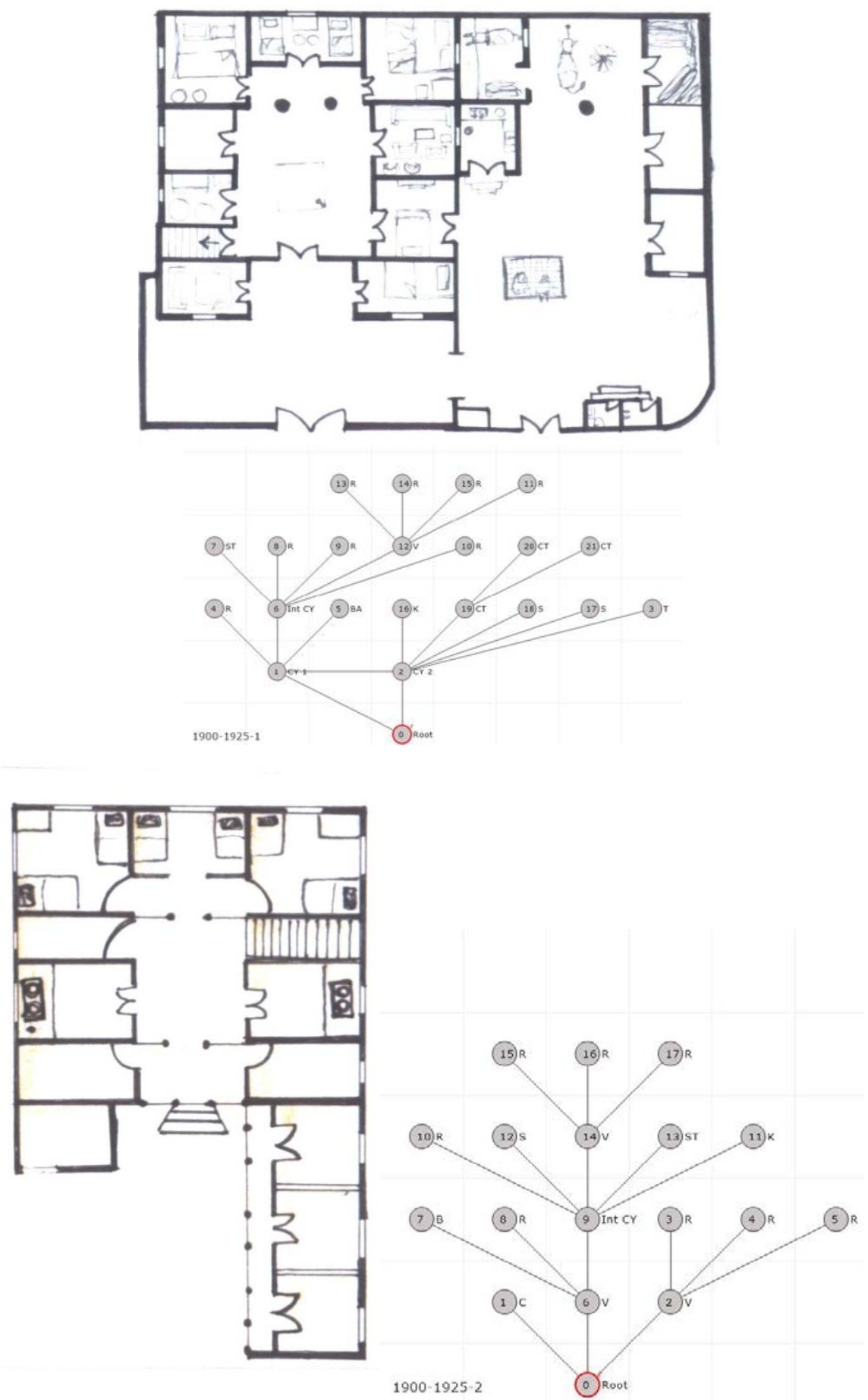

Figure 11. House plans of 1900-1925 - 1 \& 2 and their justified graph with integration and control values (Drawings by Author Studio Work) 
The Continuity of Vernacular Architecture amidst Changes, Village Shyopura, India

\begin{tabular}{|c|c|c|c|}
\hline \multicolumn{4}{|c|}{ 1900-1925-1 } \\
\hline & 1900-1925-1 & i & CV \\
\hline 1 & CY 1 & 9.54 & 2.8 \\
\hline 6 & Int CY & 8.75 & 4.4 \\
\hline 2 & CY 2 & 7.77 & 5.03 \\
\hline 0 & Root & 6.17 & 0.34 \\
\hline 12 & V & 5.83 & 4.16 \\
\hline 4 & R & 5 & 0.2 \\
\hline 5 & BA & 5 & 0.2 \\
\hline 19 & CT & 4.88 & 2.14 \\
\hline 7 & ST & 4.77 & 0.16 \\
\hline 8 & R & 4.77 & 0.16 \\
\hline 9 & R & 4.77 & 0.16 \\
\hline 10 & R & 4.77 & 0.16 \\
\hline 3 & T & 4.46 & 0.14 \\
\hline 16 & K & 4.46 & 0.14 \\
\hline 17 & S & 4.46 & 0.14 \\
\hline 18 & S & 4.46 & 0.14 \\
\hline 11 & R & 3.75 & 0.2 \\
\hline 13 & R & 3.75 & 0.2 \\
\hline 15 & R & 3.75 & 0.2 \\
\hline 20 & CT & 3.33 & 0.33 \\
\hline 21 & CT & 3.33 & 0.33 \\
\hline & Min & 3.33 & 0.14 \\
\hline & Mean & $\mathbf{5 . 0 7}$ & $\mathbf{1}$ \\
\hline & Max & 9.54 & 5.03 \\
\hline
\end{tabular}

\begin{tabular}{|c|c|c|c|}
\hline \multicolumn{4}{|c|}{ 1900-1925-2 } \\
\hline & $1900-1925-2$ & $\mathrm{i}$ & $\mathrm{CV}$ \\
\hline 6 & V & 7.15 & 2.5 \\
\hline 9 & Int CY & 7.15 & 4.5 \\
\hline 0 & Root & 5.44 & 1.5 \\
\hline 14 & V & 4.68 & 3.16 \\
\hline 2 & V & 3.88 & 3.33 \\
\hline 7 & B & 3.88 & 0.25 \\
\hline 8 & $\mathrm{R}$ & 3.88 & 0.25 \\
\hline 10 & $\mathrm{R}$ & 3.88 & 0.16 \\
\hline 11 & K & 3.88 & 0.16 \\
\hline 12 & S & 3.88 & 0.16 \\
\hline 13 & ST & 3.88 & 0.16 \\
\hline 1 & $\mathrm{C}$ & 3.31 & 0.33 \\
\hline 15 & $\mathrm{R}$ & 3.02 & 0.25 \\
\hline 16 & $\mathrm{R}$ & 3.02 & 0.25 \\
\hline 17 & $\mathrm{R}$ & 3.02 & 0.25 \\
\hline 3 & $\mathrm{R}$ & 2.66 & 0.25 \\
\hline 4 & $\mathrm{R}$ & 2.66 & 0.25 \\
\hline 5 & $\mathrm{R}$ & 2.66 & 0.25 \\
\hline & Min & 2.66 & 0.16 \\
\hline & Mean & 4 & 1 \\
\hline & Max & 7.15 & 4.5 \\
\hline
\end{tabular}

The houses constructed at that time confirm to the courtyard typology as a derivation of havelis. The house 1900-1925 - 1 has three courtyards House has an open court yard from which internal areas of house are accessed. The front area has two room accessed by verandah. The verandah open into a courtyard that the room provides access to other living areas namely room, staircase, and living. Further interior room are easily accessed through a verandah which is directly connected with the courtyard. The other court yard has service areas namely toilet, cattle space and stores and kitchen. The cattle space is also very well kept having out door feeding, indoor feeding and one room of storing the fodder for cattle. The toilet is located and significantly added at later date touching the outer boundary wall of open court yard. The court yard has multifunction usage of space. All kind of external and outdoor activities take place from daily chorus to even cooking food in evening in summer. The outer room is used to entertain and attend guest who visit the house.

The house 1900-1925-2 has internal courtyard and verandahs with control value $4.5,3.33,3.16$ and the integration value as $7.15,7.15$, and 
4.68 which is again high among other components of the house. The control value of isolated space like staircase, stores etc. are to the tune of 0.16, which his lowest of all other components of the house. The courtyard has five times more capacity to control or influence the rest other spaces. The internal verandah exerts next highest level of control value with 2.5 .

Analysis of the justified graph of both the houses reveals that maximum numbers of spaces are connected with the courtyard. The justified graph is five steps deep.

Table 1. Mean value of various attributes, Period 1900-1925

\begin{tabular}{|l|c|c|c|c|c|}
\hline Period 1900-1925 & TDn & MDn & RA & i & CV \\
\hline Mean of house 1900-1925-1 & 65.72 & 3.12 & 0.21 & 5.07 & 1 \\
\hline Mean of house 1900-1925-2 & 54 & 3.17 & 0.27 & 4 & 1 \\
\hline Mean of attributes of Period 1900-1925 & $\mathbf{5 9 . 8 6}$ & $\mathbf{3 . 1 4 5}$ & $\mathbf{0 . 2 4}$ & $\mathbf{4 . 5 3 5}$ & $\mathbf{1}$ \\
\hline
\end{tabular}

Table 1 tells us that the mean of total depth of houses is 59.86 is relatively high amongst all period sets namely 1900-1925, 1925-1950, $1950-1975,1975-2000,2000-2020$. The integration if also very high as compared to other period sets.

The JPG structure further reveals an unexpectedly complex, a "bushlike" structure. The house 1900-1925-1 has the courtyard, internal courtyard and the verandah has the highest control value 5.03, 4.4, 4.16 respectively and their integration value is $7.77,8.75$, and 5.83 respectively. The cattle, store, and toilet are the isolated spaces that have control value of 0.33-0.14. Integration values of most integrated space courtyard are three times higher than the least integrated. Rest of the rooms fall within this range. The courtyard has five times more capacity to control or influence the rest other spaces.

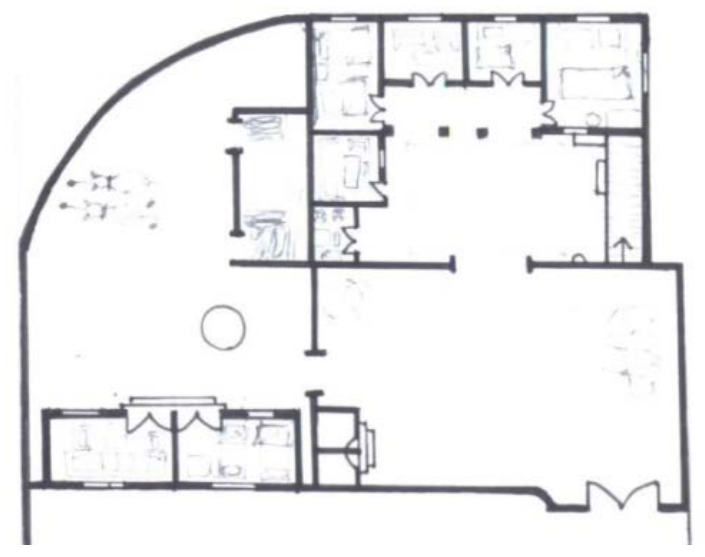


The Continuity of Vernacular Architecture amidst Changes, Village Shyopura, India
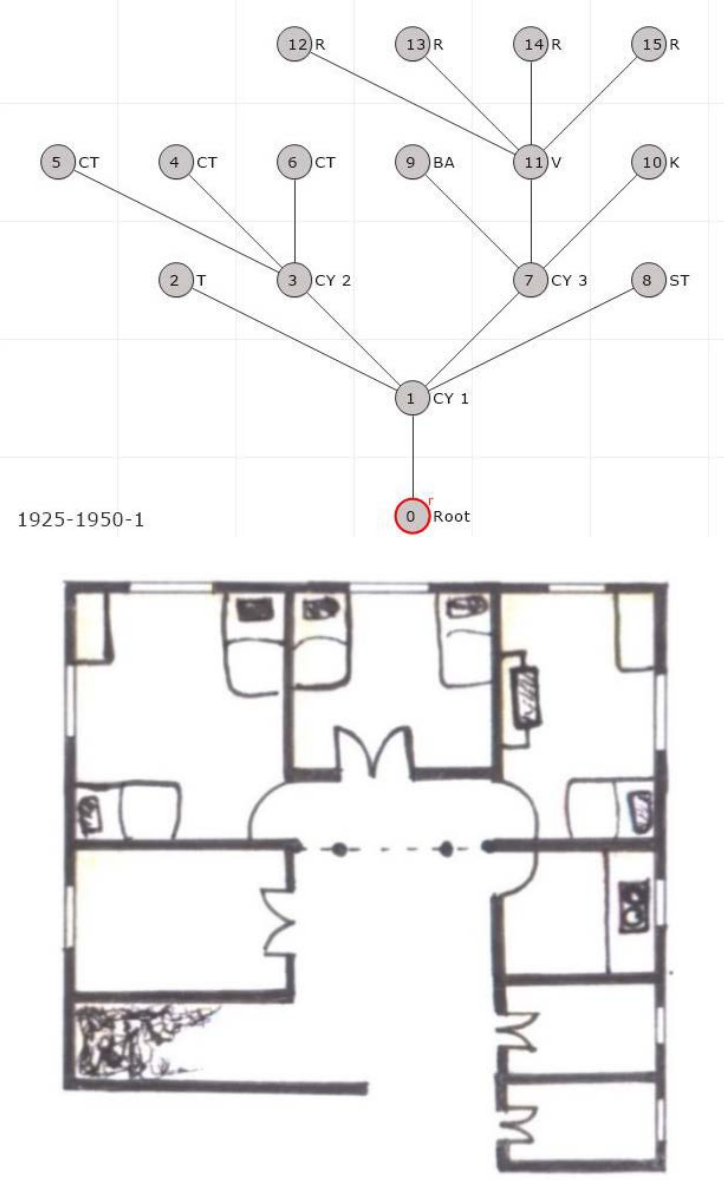

Figure 12. House plan 1925-

$1950-1 \& 2$ and their justified graph with integration and control values (Drawings by Author Studio Work)

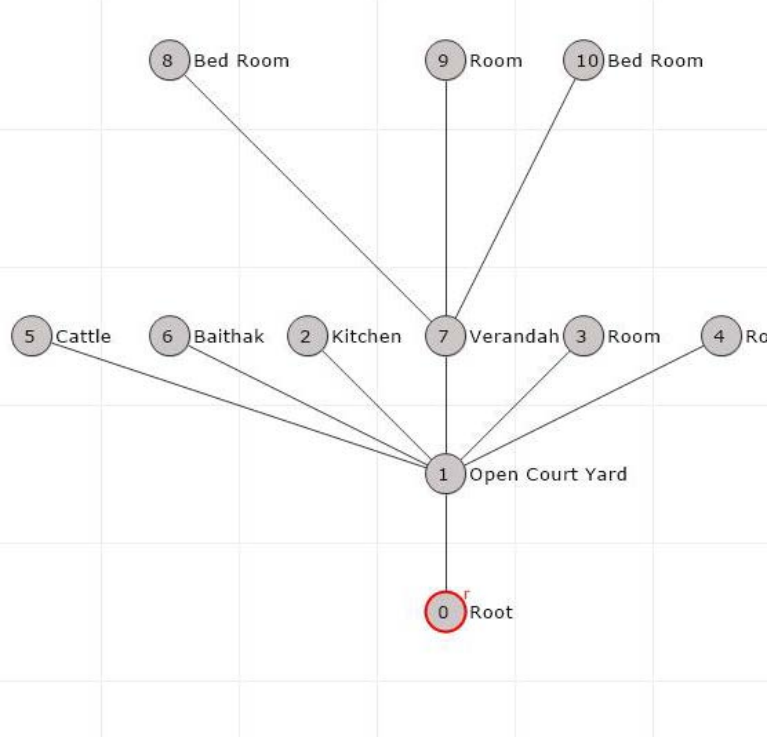




\begin{tabular}{|c|c|c|c|}
\hline \multicolumn{4}{|c|}{ 1925-1950-1 } \\
\hline & 1925-1950-1 & i & CV \\
\hline 1 & CY 1 & 7.5 & 3.5 \\
\hline 7 & CY 3 & 7.5 & 2.4 \\
\hline 11 & V & 5.25 & 4.25 \\
\hline 3 & CY 2 & 4.77 & 3.2 \\
\hline 0 & Root & 3.75 & 0.2 \\
\hline 2 & T & 3.75 & 0.2 \\
\hline 8 & ST & 3.75 & 0.2 \\
\hline 9 & BA & 3.75 & 0.25 \\
\hline 10 & K & 3.75 & 0.25 \\
\hline 12 & R & 3.08 & 0.2 \\
\hline 13 & R & 3.08 & 0.2 \\
\hline 14 & R & 3.08 & 0.2 \\
\hline 15 & R & 3.08 & 0.2 \\
\hline 4 & CT & 2.91 & 0.25 \\
\hline 5 & CT & 2.91 & 0.25 \\
\hline 6 & CT & 2.91 & 0.25 \\
\hline & & & \\
\hline & Min & 2.91 & 0.2 \\
\hline & Mean & $\mathbf{4 . 0 5}$ & $\mathbf{1}$ \\
\hline & Max & 7.5 & 4.25 \\
\hline
\end{tabular}

\begin{tabular}{|c|c|c|c|}
\hline \multicolumn{4}{|c|}{ 1925-1950-2 } \\
\hline & 1925-1950-2 & i & CV \\
\hline 1 & CY & 15 & 6.25 \\
\hline 7 & V & 7.5 & 3.14 \\
\hline 0 & Root & 3.75 & 0.14 \\
\hline 2 & CT & 3.75 & 0.14 \\
\hline 3 & BA & 3.75 & 0.14 \\
\hline 4 & K & 3.75 & 0.14 \\
\hline 5 & R & 3.75 & 0.14 \\
\hline 6 & R & 3.75 & 0.14 \\
\hline 8 & R & 3 & 0.25 \\
\hline 9 & R & 3 & 0.25 \\
\hline 10 & R & 3 & 0.25 \\
\hline & & & \\
\hline & Min & 3 & 0.14 \\
\hline & Mean & $\mathbf{4 . 9}$ & $\mathbf{1}$ \\
\hline & Max & 15 & 6.25 \\
\hline
\end{tabular}

Analysis of the justified graph both houses reveal that maximum numbers of spaces are connected with the court yard. The justified graph is four/five step deep.

Table 2. Mean value of various attributes Period 1925-1950

\begin{tabular}{|l|c|c|c|c|c|}
\hline Period 1925-1950 & TDn & MDn & RA & i & CV \\
\hline Mean of house 1925-1950-1 & 43.37 & 2.89 & 0.27 & 4.05 & 1 \\
\hline Mean of house 1925-1950- 2 & 21.45 & 2.14 & 0.25 & 4.9 & 1 \\
\hline Mean attributes of Period 1925-1950 & $\mathbf{3 2 . 4 1}$ & $\mathbf{2 . 5 1 5}$ & $\mathbf{0 . 2 6}$ & $\mathbf{4 . 4 7 5}$ & $\mathbf{1}$ \\
\hline
\end{tabular}

Table 2 tells us that the mean of total depth of houses is 32.41 is second highest amongst all period sets namely 1900-1925, 1925-1950, 1950$1975,1975-2000$ and 2000-2020. The mean integration value is 4.475 . The JPG structure of both the houses further reveals an unexpectedly complex, a "bush-like" structure. The house 1925-1950-1 has the verandah and courtyards with control values ranging from 4.25 to 2.4 and their integration value is 7.5 to 4.77 . The cattle, store, and toilet, rooms are the isolated spaces that have control value of 0.20-0.25. Integration values of most integrated space courtyard are two times higher than the least integrated. Rest of the rooms fall within this range. 
The Continuity of Vernacular Architecture amidst Changes, Village Shyopura, India

The courtyard has five times more capacity to control or influence the rest other spaces.

Houses during period 1950-1975 - An analysis (Figure 13)
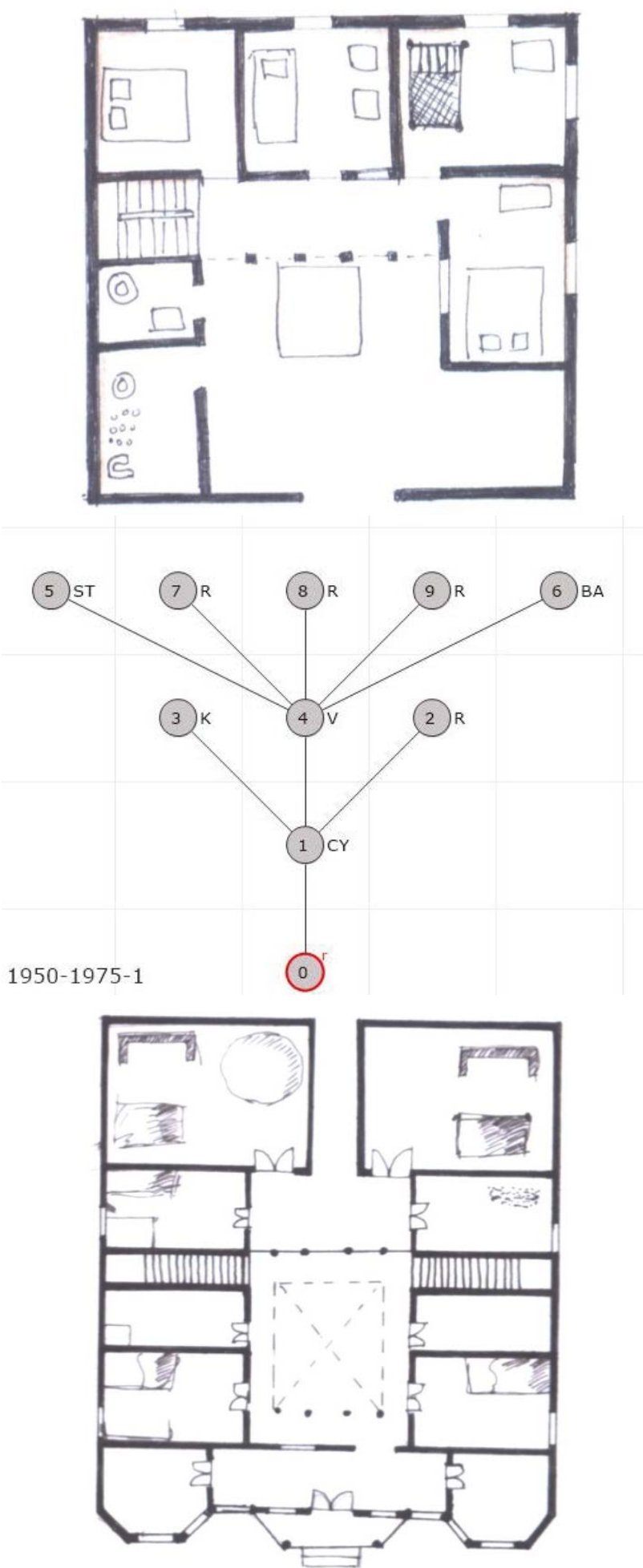


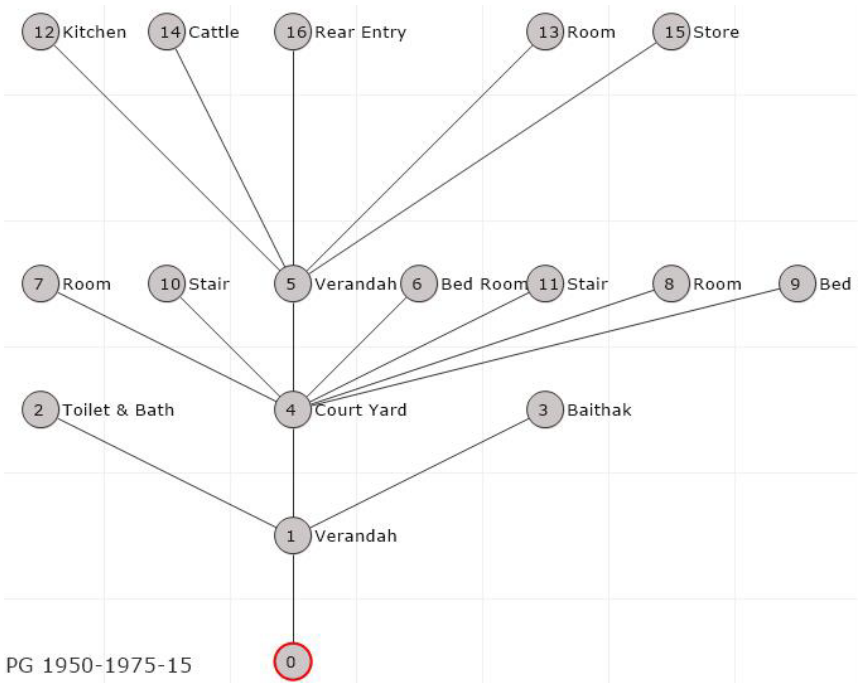

Figure 13. House plan 19501975 - 1 \& 2 and their justified graph with integration and control values (Drawings by Author Studio Work)

\begin{tabular}{|c|c|c|c|}
\hline \multicolumn{4}{|c|}{ 1950-1975-1 } \\
\hline & 1950-1975-1 & i & CV \\
\hline 4 & V & 12 & 5.25 \\
\hline 1 & CY & 7.2 & 3.16 \\
\hline 5 & ST & 3.27 & 0.16 \\
\hline 6 & BA & 3.27 & 0.16 \\
\hline 7 & R & 3.27 & 0.16 \\
\hline 8 & R & 3.27 & 0.16 \\
\hline 9 & R & 3.27 & 0.16 \\
\hline 0 & Root & 2.76 & 0.25 \\
\hline 2 & R & 2.76 & 0.25 \\
\hline 3 & K & 2.76 & 0.25 \\
\hline & & & \\
\hline & Min & 2.76 & 0.16 \\
\hline & Mean & $\mathbf{4 . 3 8}$ & $\mathbf{1}$ \\
\hline & Max & 12 & 5.25 \\
\hline
\end{tabular}

\begin{tabular}{|c|c|c|c|}
\hline \multicolumn{4}{|c|}{$1950-1975-2$} \\
\hline & $1950-1975-2$ & $\mathrm{i}$ & $\mathrm{CV}$ \\
\hline 4 & $\mathrm{CY}$ & 15 & 6.45 \\
\hline 11 & V & 8.07 & 4.12 \\
\hline 1 & V & 7 & 3.12 \\
\hline 5 & $\mathrm{R}$ & 5 & 0.12 \\
\hline 6 & $\mathrm{R}$ & 5 & 0.12 \\
\hline 7 & $\mathrm{R}$ & 5 & 0.12 \\
\hline 8 & $\mathrm{R}$ & 5 & 0.12 \\
\hline 9 & $\mathrm{R}$ & 5 & 0.12 \\
\hline 10 & $\mathrm{R}$ & 5 & 0.12 \\
\hline 12 & S & 3.88 & 0.2 \\
\hline 13 & K & 3.88 & 0.2 \\
\hline 14 & ST & 3.88 & 0.2 \\
\hline 15 & $\mathrm{ST}$ & 3.88 & 0.2 \\
\hline 0 & Root & 3.62 & 0.25 \\
\hline 2 & $\mathrm{R}$ & 3.62 & 0.25 \\
\hline 3 & BA & 3.62 & 0.25 \\
\hline & Min & 3.62 & 0.12 \\
\hline & Mean & 5.4 & 1 \\
\hline & Max & 15 & 6.45 \\
\hline
\end{tabular}

Analysis of the justified graph both houses reveal that maximum numbers of spaces are connected with the court yard. The justified graph is five step deep. 
The Continuity of Vernacular Architecture amidst Changes, Village Shyopura, India

Table 3. Mean value of various attributes, Period 1950-1975

\begin{tabular}{|l|c|c|c|c|c|}
\hline \multicolumn{1}{|c|}{ Period } & TDn & MDn & RA & i & CV \\
\hline Mean of house 1950-1975-1 & 19.2 & 2.13 & 0.28 & 4.38 & 1 \\
\hline Mean of house 1950-1975-4 & 37.25 & 2.48 & 0.21 & 5.4 & 1 \\
\hline Mean of attributes of Period & $\mathbf{2 8 . 2 2 5}$ & $\mathbf{2 . 3 0 5}$ & $\mathbf{0 . 2 4 5}$ & $\mathbf{4 . 8 9}$ & $\mathbf{1}$ \\
\hline
\end{tabular}

Table 3 tells us that the mean of total depth of houses is 28.225 is third highest amongst all period sets namely 1900-1925, 1925-1950, 1950$1975,1975-2000$ and $2000-2020$. The mean integration value is 4.89 .

Houses during period 1975-2000 - An analysis (Figure 14)
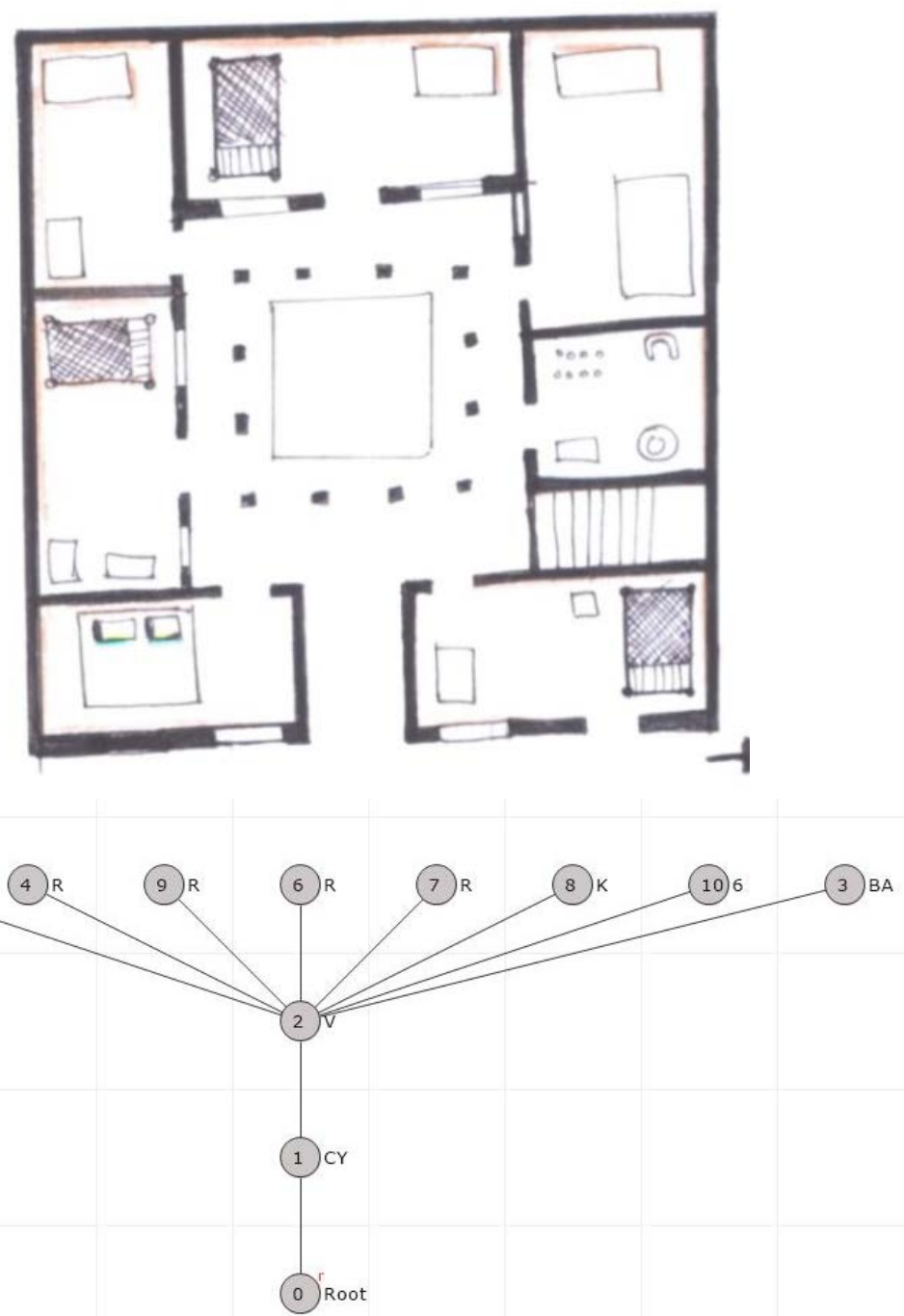


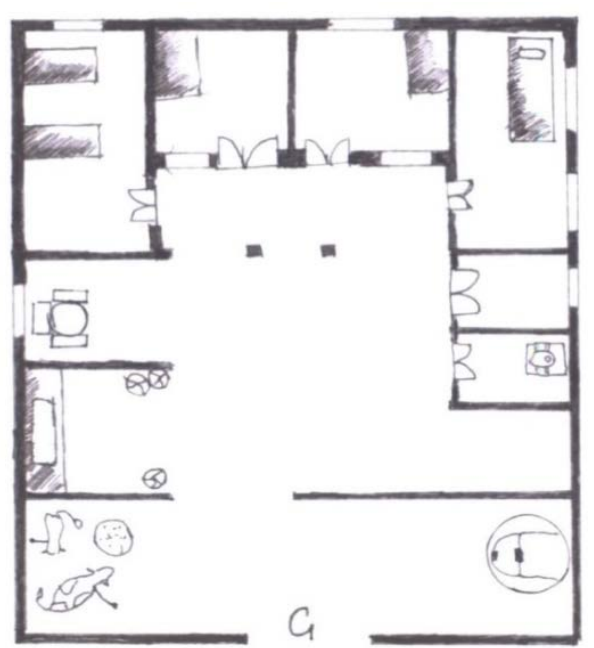

(7) Room (8) Bed Room (9) Bed Room (10)Bed Room
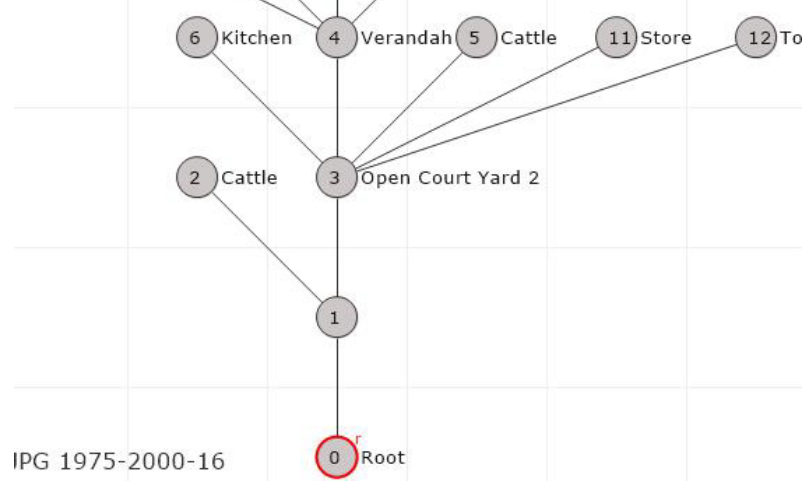

\begin{tabular}{|c|c|c|c|}
\hline \multicolumn{5}{|c|}{ 1975-2000-1 } \\
\hline & $1975-2000-1$ & $\mathrm{i}$ & $\mathrm{CV}$ \\
\hline 2 & $\mathrm{~V}$ & 45 & 8.5 \\
\hline 1 & $\mathrm{CY}$ & 5.62 & 1.11 \\
\hline 3 & $\mathrm{BA}$ & 4.5 & 0.11 \\
\hline 4 & $\mathrm{R}$ & 4.5 & 0.11 \\
\hline 5 & $\mathrm{R}$ & 4.5 & 0.11 \\
\hline 6 & $\mathrm{R}$ & 4.5 & 0.11 \\
\hline 7 & $\mathrm{R}$ & 4.5 & 0.11 \\
\hline 8 & $\mathrm{~K}$ & 4.5 & 0.11 \\
\hline 9 & $\mathrm{R}$ & 4.5 & 0.11 \\
\hline 10 & $\mathrm{R}$ & 4.5 & 0.11 \\
\hline 0 & Root & 2.64 & 0.5 \\
\hline & & & \\
\hline & Min & 2.64 & 0.11 \\
\hline & Mean & $\mathbf{8 . 1 1}$ & $\mathbf{1}$ \\
\hline & Max & 45 & 8.5 \\
\hline
\end{tabular}

\begin{tabular}{|c|c|c|c|}
\hline \multicolumn{4}{|c|}{ 1975-2000-2 } \\
\hline & $1975-2000-2$ & i & CV \\
\hline 3 & CY 2 & 11 & 4.53 \\
\hline 5 & V & 7.33 & 4.16 \\
\hline 1 & CY 1 & 5.07 & 2.16 \\
\hline 4 & K & 3.88 & 0.16 \\
\hline 6 & R & 3.88 & 0.16 \\
\hline 7 & T & 3.88 & 0.16 \\
\hline 8 & S & 3.88 & 0.16 \\
\hline 9 & R & 3.3 & 0.2 \\
\hline 10 & R & 3.3 & 0.2 \\
\hline 11 & R & 3.3 & 0.2 \\
\hline 12 & R & 3.3 & 0.2 \\
\hline 0 & Root & 2.75 & 0.33 \\
\hline 2 & CT & 2.75 & 0.33 \\
\hline & & & \\
\hline & Min & 2.75 & 0.16 \\
\hline & Mean & $\mathbf{4 . 4 3}$ & $\mathbf{1}$ \\
\hline & Max & 11 & 4.53 \\
\hline
\end{tabular}

Figure 14. House plan 1975$2000-1 \& 2$ and their justified graph with integration and control values (Drawings by Author Studio Work) 
The Continuity of Vernacular Architecture amidst Changes, Village Shyopura, India

Analysis of the justified graph all houses reveal that maximum numbers of spaces are connected with the court yard. The justified graph is five step deep.

Table 4. Mean value of various attributes, Period 1975-2000

\begin{tabular}{|l|c|c|c|c|c|}
\hline \multicolumn{1}{|c|}{ Period 1975-2000 } & TDn & MDn & RA & i & CV \\
\hline Mean of house 1975-2000-1 & 19.63 & 1.96 & 0.21 & 8.11 & 1 \\
\hline Mean of house 1975-2000-2 & 29.23 & 2.43 & 0.26 & 4.43 & 1 \\
\hline Mean attributes of Period 1975-2000 & $\mathbf{2 4 . 4 3}$ & $\mathbf{2 . 1 9 5}$ & $\mathbf{0 . 2 3 5}$ & $\mathbf{6 . 2 7}$ & $\mathbf{1}$ \\
\hline
\end{tabular}

Table 4 tells us that the mean of total depth of houses is 24.43 is fourth highest amongst all period sets namely 1900-1925, 1925-1950, 1950$1975,1975-2000$ and 2000-2020. The mean integration value is 6.27.

Houses during period 2000 - 2020 - An analysis (Figure 15)
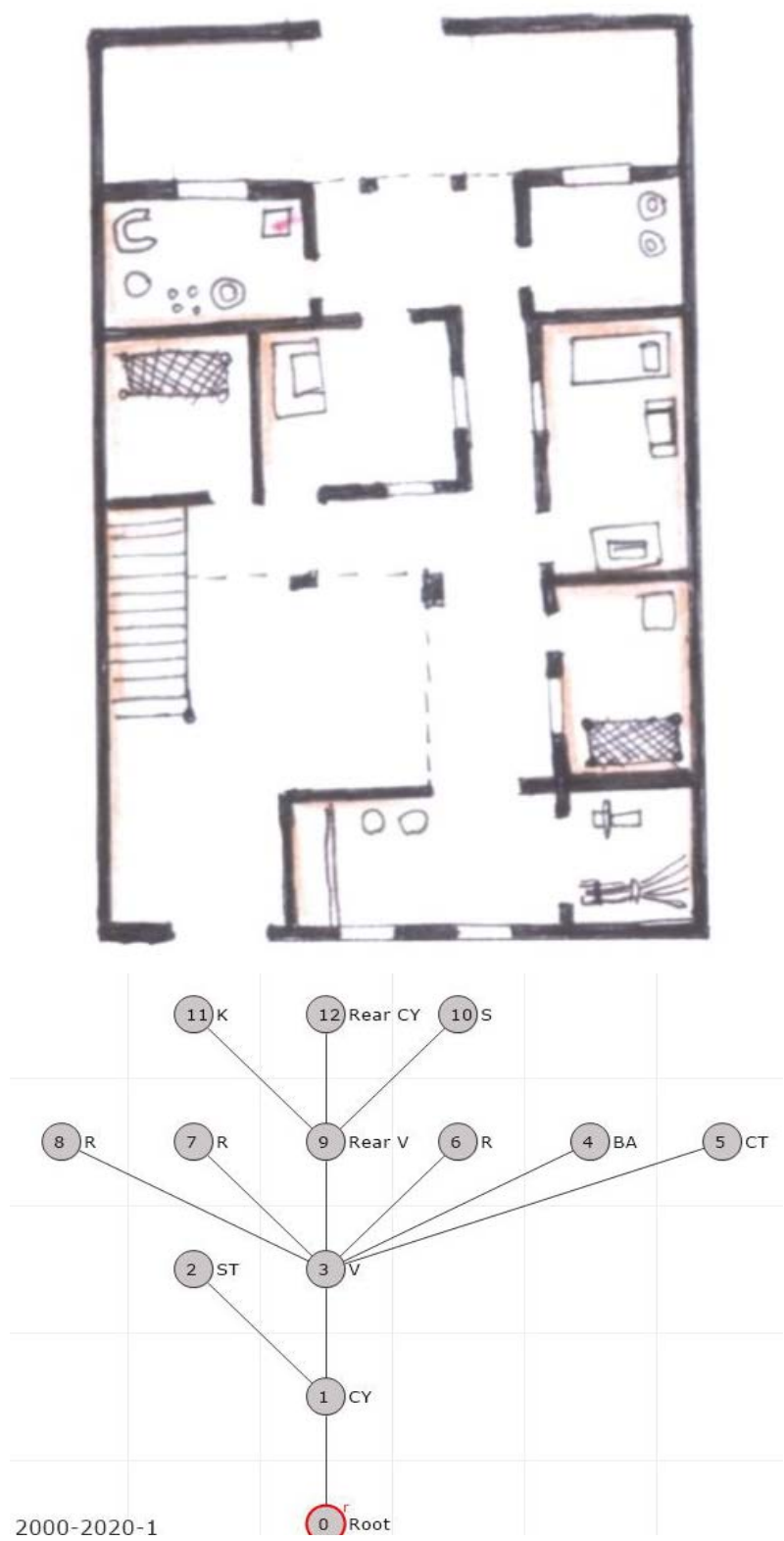


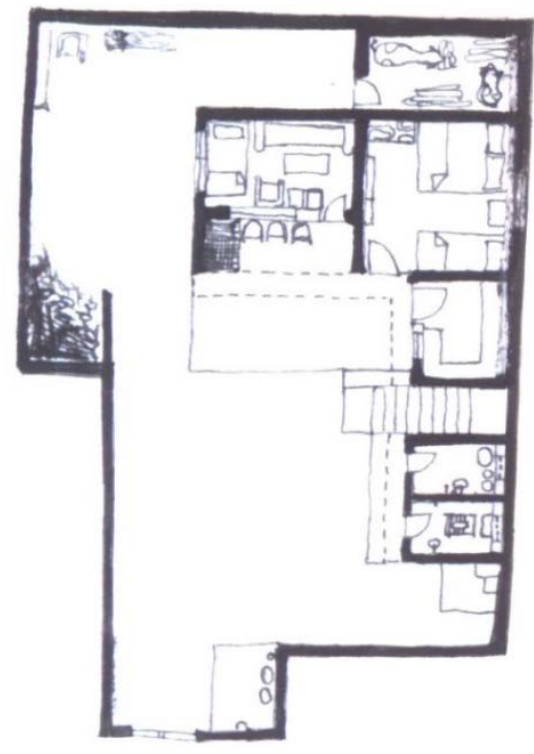

Figure 15. House plan 2000

\begin{tabular}{|c|c|c|c|}
\hline \multicolumn{4}{|c|}{ 2000-2020-1 } \\
\hline & $2000-2020-1$ & $\mathrm{i}$ & $\mathrm{CV}$ \\
\hline 3 & $\mathrm{~V}$ & 13.2 & 5.58 \\
\hline 9 & Rear V & 6.6 & 3.14 \\
\hline 1 & $\mathrm{CY}$ & 5.5 & 2.14 \\
\hline 4 & $\mathrm{BA}$ & 4.12 & 0.14 \\
\hline 5 & $\mathrm{CT}$ & 4.12 & 0.14 \\
\hline 6 & $\mathrm{R}$ & 4.12 & 0.14 \\
\hline 7 & $\mathrm{R}$ & 4.12 & 0.14 \\
\hline 8 & $\mathrm{R}$ & 4.12 & 0.14 \\
\hline 10 & S & 3.14 & 0.25 \\
\hline 11 & K & 3.14 & 0.25 \\
\hline 12 & Rear CY & 3.14 & 0.25 \\
\hline 0 & Root & 2.86 & 0.33 \\
\hline 2 & ST & 2.86 & 0.33 \\
\hline & & & \\
\hline & Min & 2.86 & 0.14 \\
\hline & Mean & $\mathbf{4 . 6 9}$ & $\mathbf{1}$ \\
\hline & Max & 13.2 & 5.58 \\
\hline
\end{tabular}

\begin{tabular}{|c|c|c|c|}
\hline \multicolumn{4}{|c|}{ 2000-2020-2 } \\
\hline & $2000-2020-2$ & i & CV \\
\hline 1 & CY & 28 & 6.5 \\
\hline 2 & Rear CY & 4.66 & 1.14 \\
\hline 0 & Root & 3.5 & 0.14 \\
\hline 3 & BA & 3.5 & 0.14 \\
\hline 4 & R & 3.5 & 0.14 \\
\hline 5 & K & 3.5 & 0.14 \\
\hline 6 & ST & 3.5 & 0.14 \\
\hline 7 & T & 3.5 & 0.14 \\
\hline 8 & CT & 2.15 & 0.5 \\
\hline & & & \\
\hline & Min & 2.15 & 0.14 \\
\hline & Mean & $\mathbf{6 . 2}$ & $\mathbf{1}$ \\
\hline & Max & 28 & 6.5 \\
\hline
\end{tabular}

- 2020 - 1 \& 2 and their justified graph with integration and control values (Drawings by Author Studio Work) 
The Continuity of Vernacular Architecture amidst Changes, Village Shyopura, India

The house $2000-2020-1$ constructed at that time does not fully confirm to the courtyard typology with a verandah as connecting space. The house has one open courtyard and one verandah all around.

Table 5. Mean value of various attributes Period 2000-2020

\begin{tabular}{|l|c|c|c|c|c|}
\hline \multicolumn{1}{|c|}{ Period 2000-2020 } & TDn & MDn & RA & i & CV \\
\hline Mean of house 2000-2020-1 & 28.61 & 2.38 & 0.25 & 4.69 & 1 \\
\hline Mean of house 2000-2020-2 & 15.55 & 1.94 & 0.26 & 6.2 & 1 \\
\hline Mean attributes of Period 2000-2020 & $\mathbf{2 2 . 0 8}$ & $\mathbf{2 . 1 6}$ & $\mathbf{0 . 2 5 5}$ & $\mathbf{5 . 4 4 5}$ & $\mathbf{1}$ \\
\hline
\end{tabular}

Table 5 tells us that the mean of total depth of houses is 22.08 is least amongst all period sets namely 1900-1925, 1925-1950, 1950-1975, 1975-2000 and 2000-2020. The mean integration value is 5.445 .

The house 1200-2020-2 has one courtyard in front and one in the rear with control value 6.5 and integration value as 28 which is again high among other components of the house. The control value of isolated space like toilet, kitchen, store and other internal rooms etc. are to the tune of 0.14-1.5, which his lowest of all other components of the house. The affluence has been reflected in the size of house, courtyard and the ornamentation of the arcade around. There were three types of courtyard identified one is the open court that precedes the building.

Second is the courtyard within the building surrounded by the arcade. The interaction with the family members revealed that the courtyard is used by family members at different point of time for various activities. Since these were the small houses a single internal courtyard is the only relieving space for outdoor activities. The Baithak (a room where the outsiders are entertained) is preferably placed as the first room of the house. The extended and the large families shared the same space. the toilet and bathing space are usually placed and attached to the external walls of the courtyard facing inside. Although, the walls are high enough to protect the privacy.

Another activity that was most common in the courtyard in rear courtyard is preferably the space where the cattle were kept. That space usually has two to three rooms. One where the cattle are tied during hot day and the other where the fodder is kept and stocked. In the morning and evening the cattle are taken outside in the open court and kept there for some time. The courtyard has a very direct relationship and connection with other spaces of house. A house generally has social space (Baithak/outer room), private space (courtyard) and service space cattle courtyard, toilet, kitchen.

The local climate and season has impact on the usage of courtyard space. usually it is used all day long. The internal courtyard is an introvert space, whereas the outer court yard is a extrovert space whir service areas like toilets, and for cattle etc are placed and is also used to entertain external guest in open. 
In some of the cases there were large numbers of rooms. The residents informed that this is either due to extended family or they are multifunctional in nature

Rooms although lacked in furniture. It supports the similar outcomes and reasoning by Nevnihal Erdoğan (Erdoğan, 2017).

\section{CONCLUSION AND RECOMMENDATIONS}

This paper is an attempt to identify the continuity of the spatial configuration with respect to the courtyard in vernacular village of Rajasthan. Besides reflecting some socio-cultural reasons it supports the climatic compulsions as well that shape the spatial relationships between various components of a house. The Courtyard, service spaces, private and public spaces are arranged hierarchically. The courtyard has provisions of multipurpose usages by all members of the house. Thus, it becomes a shared space for benefits of all.

A typical house has one, two or three types of such courtyard spaces adjacent to verandah. They are open semi open or may be closed i.e surrounded by arcade and also a roof. Of all such case houses the houses with internal open courtyard is used most by all members of house, even females members throughout the year. The existence of courtyard is still continued in some form and size or the other

While discussing the routine activity in space the residents revealed that courtyard is a good sleeping space during summer outside whereas it multifunctional space. the morning food and evening food is usually cooked in the courtyard outside. Till the sun shines high in the sky or the weather permits to do so. The ladies are usually free time during mid of day and is spent in gossiping and socialising. Thus it changes its sanctity form a private to a semis private space where guest are also entertained. The toilets in the courtyard house are always located on one of the wall of the courtyard. This is accessible from the house through the courtyard. Toilets and personal bathing places are located usually together. This enabled to keep the house environment clean and fresh

\section{The Courtyard - A Concept and Sustainable Vernacular Form}

Ibrahim has very well explained the role of courtyard in house plan type in hot arid zones across world. Additionally to it being a functional he cited it to be having a very significant role for climate control.

Courtyards, is a prototype plan form and play two important roles. One is that it sustains the climatic conditions of the region as "the major function for the courtyard is to control the environment and to maintain suitable weather for the humans", as well as to create an inner environment, that provides privacy and solitude environment. The second aspect is the social one. It includes provisions of a multipurpose space that is for usage of everyone and for much type of social-o-cultural activities. His research demonstrated that 'the courtyards' design is an essential part of the vernacular traditional architecture. It serves the principles of sustainability as a multi-dimensional concept that includes 
Figure 16. Graph showing inequality genotype data; divided by house (Graph by Author)
The Continuity of Vernacular Architecture amidst Changes, Village Shyopura, India

economic, social and environmental dimensions". (Ibrahim, 2019, p 16). Environmentally, a courtyard acts as a thermal regulator. In ideal conditions it is a small space in the middle of the house surrounded by rooms where different functions take place providing shade and cool because of the surrounding high walls. Simultaneously the It separates the two domains of public and private.

\section{Identifying the Continuity}

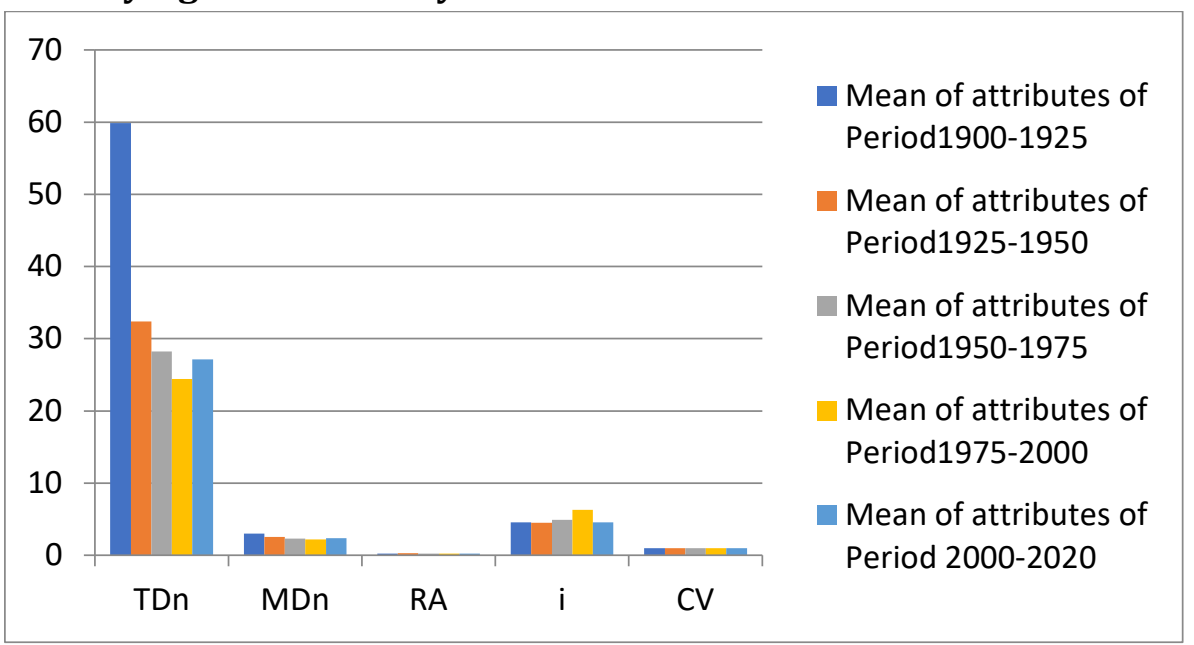

Table 6. Comparative means of all attributes across 5 periods

\begin{tabular}{|c|c|c|c|c|c|}
\hline Period & TDn & MDn & RA & i & CV \\
\hline Mean of attributes of Period1900-1925 & 59.86 & 3014 & 0.24 & 4.53 & 1 \\
\hline Mean of attributes of Period1925-1950 & 32.41 & 2.515 & 0.26 & 4.475 & 1 \\
\hline Mean of attributes of Period1950-1975 & 28.225 & 2.305 & 0.245 & 4.89 & 1 \\
\hline Mean of attributes of Period1975-2000 & 24.43 & 2.195 & 0.235 & 6.27 & 1 \\
\hline Mean of attributes of Period 2000-2020 & 27.135 & 2.355 & 0.255 & 4.56 & 1 \\
\hline
\end{tabular}

The above table justifies the diminishing tree like structure genotypes from 1900-1925 till 2000-2020 the average total depth has decreased from 59.86 to 27.135 . This amounts to $56 \%$ decrease in the tree like formation and grouping and connectivity of spaces. This can be attributed to the fact that the new houses are nuclear ones and have less numbers of spaces and thus the connectivity and dependency is also reduced with courtyard.

This process also produces a type of inequality genotype. In order to attain the overall image of genotype and transformation therein six important sectors have been identified after field visit. These are namely courtyard, verandah, external room, internal room Kitchin, and service areas like cattle, toilets and stair case, the mean integration values of these functional areas were considered. 
Ajay Kaushik

Table 7. Mean value Total Deptjh (TDn) of various sectors/spaces across all periods

\begin{tabular}{|c|c|c|c|c|c|c|}
\hline Period & Courtyard & Verandah & $\begin{array}{c}\text { Ext. } \\
\text { Roo } \\
\text { m }\end{array}$ & $\begin{array}{c}\text { Int. } \\
\text { Room }\end{array}$ & Kitchen & $\begin{array}{c}\text { Service area } \\
- \\
\text { Cattle/Store }\end{array}$ \\
\hline $\begin{array}{c}\text { Period 1900- } \\
\text { 1925 }\end{array}$ & 53 & 54.5 & 65.5 & 69.5 & 60 & 32 \\
\hline $\begin{array}{c}\text { Period 1925- } \\
\text { 1950 }\end{array}$ & 21 & 25.5 & 32.5 & 35.5 & 34 & 25.5 \\
\hline $\begin{array}{c}\text { Period 1950- } \\
\text { 1975 }\end{array}$ & 18 & 21 & 33 & 28 & 32 & 31 \\
\hline $\begin{array}{c}\text { Period 1975- } \\
\mathbf{2 0 0 0}\end{array}$ & 21.5 & 16 & 24.5 & 26 & 24.5 & 24.5 \\
\hline $\begin{array}{c}\text { Period 2000- } \\
\mathbf{2 0 2 0}\end{array}$ & 25 & 8.5 & 27 & 27 & 29.5 & 32 \\
\hline \multicolumn{1}{|l|}{} & & & & & \\
\hline \multicolumn{2}{|l|}{} & 125.5 & 182.5 & 186 & 180 & 145 \\
\hline $\begin{array}{c}\text { Mean of } \\
\text { attributes of } \\
\text { all periods }\end{array}$ & 27.7 & 25.1 & 36.5 & 37.2 & 36 & 29 \\
\hline
\end{tabular}

Table 8. Mean value of integration (i) of various sectors/spaces across all periods

\begin{tabular}{|c|c|c|c|c|c|c|}
\hline Period & Courtyard & Verandah & $\begin{array}{l}\text { Ext. } \\
\text { Room }\end{array}$ & $\begin{array}{l}\text { Int. } \\
\text { Room }\end{array}$ & Kitchen & $\begin{array}{c}\text { Service } \\
\text { area - } \\
\text { Cattle/Store } \\
\end{array}$ \\
\hline & i & $\mathbf{i}$ & i & $\mathbf{i}$ & $\mathbf{i}$ & $\mathbf{i}$ \\
\hline $\begin{array}{c}\text { Period 1900- } \\
1925\end{array}$ & 5.54 & 4.855 & 3.83 & 3.385 & 4.17 & 2.44 \\
\hline $\begin{array}{c}\text { Period 1925- } \\
1950\end{array}$ & 11.25 & 6.375 & 3.75 & 3.415 & 3.375 & 1.45 \\
\hline $\begin{array}{l}\text { Period 1950- } \\
1975\end{array}$ & 11.1 & 9.5 & 3.19 & 4.135 & 3.32 & 3.57 \\
\hline $\begin{array}{l}\text { Period 1975- } \\
2000\end{array}$ & 5.345 & 26.165 & 4.19 & 3.9 & 4.19 & 4.19 \\
\hline $\begin{array}{l}\text { Period 2000- } \\
2020 \\
\end{array}$ & 4.58 & 6.6 & 3.89 & 3.89 & 3.4 & 3.16 \\
\hline & 37.815 & 53.495 & 18.85 & 18.725 & 18.46 & 14.82 \\
\hline $\begin{array}{c}\text { Mean of } \\
\text { attributes of } \\
\text { all periods }\end{array}$ & 7.563 & 10.699 & 3.77 & 3.745 & 3.691 & 2.96 \\
\hline
\end{tabular}

Table 9. Mean value Control value (Cv) of various sectors/spaces across all periods

\begin{tabular}{|c|c|c|c|c|c|c|}
\hline Period & Courtyard & Verandah & Ext. Room & Int. Room & Kitchen & $\begin{array}{c}\text { Service } \\
\text { area - } \\
\text { Cattle/Store }\end{array}$ \\
\hline & CV & CV & CV & CV & CV & CV \\
\hline $\begin{array}{c}\text { Period 1900- } \\
1925\end{array}$ & 2.68 & 3.745 & 0.225 & 0.225 & 0.15 & 1.07 \\
\hline $\begin{array}{c}\text { Period 1925- } \\
1950\end{array}$ & 4.875 & 3.695 & 0.195 & 0.17 & 0.25 & 0.125 \\
\hline $\begin{array}{c}\text { Period 1950- } \\
1975\end{array}$ & 4.805 & 4.185 & 0.25 & 0.14 & 0.225 & 0.18 \\
\hline $\begin{array}{c}\text { Period 1975- } \\
2000\end{array}$ & 1.635 & 6.33 & 0.135 & 0.155 & 0.135 & 0.135 \\
\hline $\begin{array}{c}\text { Period 2000- } \\
2020\end{array}$ & 1.695 & 2.79 & 0.14 & 0.14 & 0.195 & 0.32 \\
\hline & 15.69 & 20.745 & 0.945 & 0.83 & 0.955 & 1.83 \\
\hline $\begin{array}{l}\text { Mean of } \\
\text { attributes of all } \\
\text { periods }\end{array}$ & 3.138 & 4.149 & 0.189 & 0.166 & 0.191 & 0.366 \\
\hline
\end{tabular}


The Continuity of Vernacular Architecture amidst Changes, Village Shyopura, India

The close analysis reveals that out of 10 case study houses 6 houses have courtyard as one of the most integrated space and the others have verandahs (Table $7,8,9)$.

In case of both the houses built during 1900-1925 courtyard with average integration value at 5.54 and the adjacent verandah (i - 4.85) space are one of the most integrated space and the cattle/service space and internal room are the least integrated ones. Courtyard is more than twice integrated with i value at 2.44 merely. The average control vale of courtyard is 2.68 and verandah is 3.74 which are highest among all spaces. This means that verandah and the courtyard are the spaces that provide access and control the connectivity with maximum number of spaces in the houses. The service spaces are with least control value (1.07).

In case of two case study houses built during 1925-1950 the courtyard with average integration value at 11.2 and the adjacent verandah space is average integrated at 6.37 are one of the most integrated space and the cattle/service space with average integration value at 1.45 are the least integrated ones. Courtyard is 3.5 times more integrated. The average control vale of courtyard is 4.875 and verandah is 3.69 which are highest among all spaces. This means that courtyards are the spaces that provide access and control the connectivity with maximum number of spaces in the houses. The service spaces are with least control value (0.12).

In case of case study houses built during 1950-1750 the courtyard with average integration value at 11.10 and the adjacent verandah space is average integrated at 9.5 are one of the most integrated space and the cattle/service space with average integration value at 3.57 are the least integrated ones. Courtyard is 4 times more integrated. The average control vale of courtyard is 4.80 and verandah is 4.18 which are highest among all spaces. This means that courtyards are the spaces that provide access and control the connectivity with maximum number of spaces in the houses. The service spaces are with least control value (0.18).

In case of case study houses built during 1975-2000 the courtyard with average integration value at 5.34 and the adjacent verandah space is average integrated at 26.81 are one of the most integrated space and the cattle/service space with average integration value at 4.19 are the least integrated ones. The further study reveals that the verandah has been given better preference over courtyard and rooms are accessible through verandahs. The average control vale of courtyard is 1.635 and verandah is 6.33 which are highest among all spaces. This means that verandahs are the spaces that provide access and control the connectivity with maximum number of spaces in the houses. The service spaces are with least control value (0.13).

In case of case study houses built during 2000-2020 the courtyard with average integration value at 4.58 and the adjacent verandah space is average integrated at 36.6 are one of the most integrated space and the 
cattle/service space with average integration value at 3.16 are the least integrated ones. Courtyard is 1.5 times more integrated. Courtyard tend to connect directly with outside. The average control value of verandah is 2.79 which is highest among all spaces. This means that verandahs are the spaces that provide access and control the connectivity with maximum number of spaces in the houses. The service spaces are with least control value (0.32).

Of all the 10 cases the courtyard has significant integration values in 7 cases these also exert the highest spatial control. This is due to the fact that these courtyard and verandah space have highest numbers of links and connectivity.

Comparing the mean values of all period it can be inferred that the average integration values all periods of courtyard 7.563, verandah 10.69 and service spaces are 2.96. the courtyard on the whole and on an average is 2.5 times more integrated than fringe service spaces of housing typology. The average control value of all periods of courtyard is 31.36 and that of verandah is 4.149 and of service spaces is 0.36 . Thus courtyard exerts 100 times more control as compared to the control of service spaces in housing typology.

The jpg graph is a bush and tree like structure with most of branches/ spaces generating from courtyard space. Thus it is inferred that despite the changing family structure there is a continuity of courtyard genotype in village Sheopura.

Table 10. Mean integration percentages across all periods

\begin{tabular}{|l|c|c|c|c|c|}
\hline $\begin{array}{l}\text { Mean integration \% } \\
\text { Spaces }\end{array}$ & $\begin{array}{c}1900- \\
1925\end{array}$ & $\begin{array}{c}1925- \\
1950\end{array}$ & $\begin{array}{c}1950- \\
1975\end{array}$ & $\begin{array}{c}1975- \\
2000\end{array}$ & $\begin{array}{c}2000- \\
2020\end{array}$ \\
\hline $\begin{array}{l}\text { Low } \leq 3 \\
\text { (Service Sector) }\end{array}$ & 28 & 18 & 0 & 15 & 8 \\
\hline $\begin{array}{l}\text { Medium 3-5 (Private } \\
\text { Sector) }\end{array}$ & 50 & 62 & 44 & 61 & 78 \\
\hline $\begin{array}{l}\text { High } \geq 5 \\
\text { (Social Sector) }\end{array}$ & 22 & 20 & 56 & 24 & 14 \\
\hline
\end{tabular}

The analysis of tables 10 above is interpreted as follows. It is understood that the social spaces are having maximum integration percentages ( $44 \%$ to $78 \%$ ) and maximum of these spaces have medium to high level of integration values i.e. more than 3 . The average of low integration value i.e less than 3 is merely $14 \%$ during all periods. This means that over a period of 125 years the continuity of spatial location and integration of social spaces has still existed. The service sector/areas have the least integration values and overall percentage (15\%). Hence these are most segregated and are connected furthermost. Thus, it is concluded that social sector is highly integrated with least depth in maximum number of case study houses.

Meaning thereby a continuity if spatial structure of vernacular

architecture in village Shyopura, Rajasthan. 
The Continuity of Vernacular Architecture amidst Changes, Village Shyopura, India

\section{ACKNOWLEDGEMENTS}

Author is thankful to the team of $2^{\text {nd }}$ year students of Department of Architecture of Pandit Lakhmi Chand State University of Performing and Visual Arts, Rohtak for having conducted the site survey of village Shyopura as vernacular studio in $2^{\text {nd }}$ year of B. Arch. Course. The academic tour was sponsored by Pandit Lakhmi Chand State University of Performing and Visual Arts, Rohtak.

\section{CONFLICT OF INTEREST}

There is no conflict of interest in the paper.

\section{FINANCIAL DISCLOSURE}

Author declares that the tour was funded by our University - Pandit Lakhmi Chand State University of Performing \& Visual Arts, Rohtak. Haryana.

\section{ETHICS COMMITTEE APPROVAL}

Ethics committee approval was not required for this article.

\section{LEGAL PUBLIC/PRIVATE PERMISSIONS}

In this research the necessary permissions were obtained from the relevant participant during in-depth survey, interview, focus group interview, observation at site itself.

\section{REFERENCES}

Agrawal, A., Jain, R. K., Ahuja, R. (2006). Shekhawati: Urbanism in the semi-desert of India A climatic stud. $23^{\text {rd }}$ International Conference on Passive and Low Energy Architecture, 6-8 September 2006, pp. 1-7, Geneva.

Amorim, L. (1997). The Sectors' Paradigm Understanding modern functionalism and its effects in configuring domestic space, First Space Syntax International Symposium, 1997, pp. 18.1-18.14, London.

Hillier; B., Hanson, J., (1984). The social logic of space. Cambridge University Press.

BIS. (1978). Indian Standards, Guide for heat insulation of nonindustrial buildings.

Dettlaff, W. (2014) 'Space syntax analysis - methodology of understanding the space', PhD Interdisciplinary Journal, pp 283-291.

Directorate of Census Operations Rajasthan (2011) 'District census handbook Jhunjhunu', Village and Town Wise Primary Census Abstract.

Gozde Uyar, S. G. (2017). A configurational approach to vernacular domestic architecture, Eleventh Space Syntax Symposium, 2011, pp 32.1-32.16, Lisbon.

Ibrahim, I. (2019). Eco-traditional courtyard houses in uae: A case study of the sharjah museums. WIT Transactions on the Built Environment, 183, pp 15-24. 
ICOMOS. (1999) Charter on the built vernacular heritage (1999).

Jain, S. (2002) 'The Havelis of Rajasthan', PhD thesis, De Montfort University, Leicester.

Jiang, B., Claramunt, C., Klarqvist, B. (2000). An Integration of Space Syntax into GIS for Urban Planning and Design. International Journal of Applied Earth Observation and Geoinformation, 2, pp 1-18.

Kazimee, B. A. (2008). Learning from vernacular architecture: Sustainability and cultural conformity. WIT Transactions on Ecology and the Environment, 113, 3-13.

Mahmoud, A. H., Omar, R. H. (2015) 'Planting design for urban parks: Space syntax as a landscape design assessment tool', Frontiers of Architectural Research. Elsevier, 4(1), pp. 35-45.

Manum, B., Rusten, E., Benze, P. (2005). AGRAPH, Software for Drawing and Calculating Space Syntax "Node-Graphs" and Space Syntax "AxialMaps." Fifth International Space Syntax Symposium, pp 97-101, Delft Retrieved from http://www.ntnu.no/ab/spacesyntax/

Erdoğan, N. (2017). Cultural Traditions and Domestic Space Ağaçbekler Home. Sage open, july - September 2017, 1-16.

Ostwald, M. J. (2011). A Justified Plan Graph Analysis of the Early Houses (1975-1982) of Glenn Murcutt. Nexus Network Journal, 13(3), 737-762.

Pal, B., Dhot, S., Kaur, P., Dec, R., Jan, A. (2018). Learning from planning and designing of havelis of malwa region of Punjab as a role model of sustainable built environment. International Journal of Research and Analytical Reviews 5(1), 28-34.

Monteiro, C. G.(1997). Activity analysis in houses of Recife, First International Space Syntax Symposium, pp 20.1-20.14, London.

Rapoport, A. (1969) 'House Form and Culture' Prentice-Hall, Inc. Englewood Cl, NJ.

Rapoport, A. (1979). An Interview With Amos Rapoport on Vernacular Architecture. M.E.T.U Journal of the Faculty of Architecture, 5(2), 113126.

Shirvastva, U, DRONAH (2008) 'Context: Special Issue on UNESCO', Context: Built, Living and Natural, 5(1), 91-100.

Sinha, S., Varshney, M. (2017). Cultural tourism in Rajasthan: a strategic planning approach for Mandawa. International Journal on Emerging Technologies, 8(1), 97-102.

Verma, T., Brar, T. S. (2020). Vernacular Havelis of Bikaner : Indigenous Method for Thermal Comfort. International Journal on Emerging Technologies 8(1), 1-6.

\section{Resume}

Dr. Ajay Kaushik received his Bachelor and Master's Degree in Architecture from School of Planning and Architecture, New Delhi in 1999. He is Head of Department of Planning and Architecture at Pandit Lakhmi Chand State University of Performing and Visual Arts, Rohtak. History and Design are his favourite subjects. 